\title{
THE CANON: THE FUNDAMENTAL PASTORAL RULE OF THE CHURCH. AN ETYMOLOGICAL, SEMANTIC AND THEOLOGICAL APPROACH
}

\author{
Ph.D. George GRIGORIȚĂ \\ Faculty of Orthodox Theology "Justinian Patriarch" - University of Bucharest, \\ ROMANIA, \\ E-mail: george.grigorita@unibuc.ro
}

\begin{abstract}

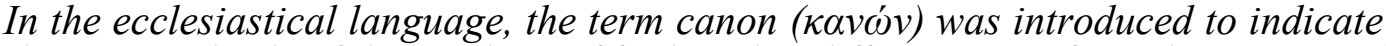
the practical rule of the teaching of faith and to differentiate it from the concept of law (lex - vouos). This term therefore identifies any rule of the Church that puts into practice the doctrine of faith, defined by dogmas. The expression "holy canons" defines the collection of canons approved and received by the Church. Over time, some authors have made various proposals on the role of holy canons in the Church, oscillating them to be canceled as unsubstantiated until they say that their text would have been revealed. According to the doctrine and practice of the Church, the holy canons apply pastorally to ecclesial life, customized for each individual situation. Therefore, in the Church, it is necessary for all activities to take into account the fundamental principles contained in the holy canons, so that the life of the Church conforms to the teaching of christian-orthodox faith.
\end{abstract}

Keywords: canon, canon law, ecclesiastical law, theology of canon law; orthodox theology.

\section{INTRODUCTION}

Common language employs quite frequently the term canon to designate a rule or a norm specific to a particular field. Theological language also uses the term canon to identify certain specific ecclesiastical regulations. Sometimes, however, the term canon also means law legal system), thus the phrase „,canon law” designating the „law (legal system) of the Church”. In other contexts, the term canon is employed as to mean dogma, hence the phrase ,canon of the faith".

Until the $20^{\text {th }}$ century, the role and significance of canons had never been questioned in the Church; on the contrary, the prefaces of the canon collections would point out that the authority of holy canons equals the authority of the Gospels' text (the best example is the Pedalion, also known as The Rudder). Since the turn of the $21^{\text {st }}$ century, however, some authors have expressed divergent views on the validity and applicability of canons. To some authors, canons are nothing but vestiges of Church life dating from a particular epoch, but having no practical relevance to the present life of the Church.

According to other authors, the canons are the main referential in ecclesial life, therefore they absolutely have to be followed literally, in strict accordance to their text. Yet other authors have given canons a fundamental and constant role in the organization and operation of the Church, indicating as mandatory only the fundamental principles they contain, to be observed in the Church.

Therefore, an etymological and semantic analysis of the term canon, and a description of its evolution over time as well as its current meaning, are a didactic and pastoral necessity. It is also highly useful and necessary to investigate the relationship between canons and dogmas, and the one between canons and laws. 


\section{THE ETYMOLOGY AND MEANING OF THE TERM „CANON”}

In light of communion ecclesiology, the Orthodox Church defines itself - canonically - as the communion of autocephalous Churches, who have to preserve the doctrinal, canonical and liturgical unity with the universal Orthodox Church. In practice, the preservation of canonical unity in the Church, is achieved by each autocephalous Church complying with, and applying the holy canons. For a better understanding of the "holy canons", or the "holy and divine canons", it is necessary to explain first the etymology of this term, then to present the current significance of the term canon in the Orthodox theology.

Etymologically, the word canon originates in the Greek кavóv (canon), derived from the Hebrew qaneh, meaning a rule, norm, guideline, model, principle, benchmark ${ }^{2}$. The Hebrew term qaneh is usually translated by reed (the scientific name is Arundo donax), but is also designates a straight, tubular object, employed as a measuring rod. However, some experts have put forth other possible etymologies for the word $\kappa a v \omega$ v, postulating a Sumerian-Akkadian origin of the term ${ }^{3}$.

One of the $12^{\text {th }}$ century Byzantine canonists - Ioannis Zonaras (1042-1130), in his commentaries (scholia) to the pastoral epistle on feasts written by St Athanasius the Great $(\dagger 373)$ attempted a metaphorical explanation for the etymology of the term $\kappa \alpha v \omega$, asserting that it designated a wooden tool used by craftsmen to polish wooden or stone items, more precisely to remove the irregularities of the respective object; the Church had chosen this term precisely in order to highlight the soteriological character of the canon, which is prescribed so as to correct any irregularities that may have occurred in the lives of the faithful, in order to bring them in communion with Lord Jesus Christ, our Saviour ${ }^{4}$.

In the Old Testament, the term qaneh was employed to designate a measuring rod, or a pole as it is translated in the Romanian Bible books (Ezekiel 40,3) - the unit of length employed to indicate the dimensions of the Temple in the vision of Ezekiel (40, 3-5). In the Septuagint, the term $\kappa \alpha v \omega ́ v$ occurs only three times (Micah 7, 4; Judith 13, 6; 4 Maccabees 7,21) each with a different meaning 5 .

During the first Christian century, the term kavóv was used to mean „,moral norm/ guideline", as the Holy Apostle Paul employs it in his epistles (II Cor. X, 13, 15, 16, Gal. VI, 16, Philip. III, 16). At the end of the first Christian century, Saint Clement of Rome, in his Epistle to the

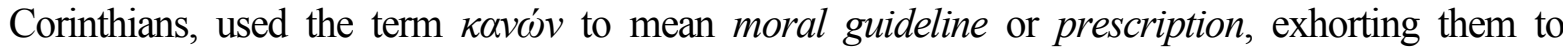
abandon the vain, daily and worldly cares and instead refer to ,the holy, lofty guidance offered by our tradition" $"$. Thus, to the Christians of the first three centuries, canon meant

\footnotetext{
${ }^{1}$ For a detailed analysis of the concept of canon in the Church, as well as the collection of canons entitled ,The Holy and Divine Canons of the Church" (canon 1, the Seventh Ecumenical Council), see my recent work on this topic: Georgică Grigorităă, Sfintele și dumnezeieștile canoane în Biserică: între tradiție eclezială și necesitate pastorală. O analiză a izvoarelor teologiei canonice în actualul context ecleziologic, Bucharest, 2017.

${ }_{2}^{2}$ Cf. Maurice Lalmant, „Canon”, in Raoul NAz (ed.), Dictionnaire de droit canonique, t. II, Paris, 1937, col. 1283-1284; Heinz Ohme, Kanon ekklesiastikos. Die Bedeutung des altkirchlichen Kanonbegriffes, Berlin-New York, 1998, pp. 21-28; „Kanon I (begriff)", in Franz Joseph Dölger (ed.), Reallexikon für Antike und Christentum, vol. 20, Stuttgart, 2004, pp. 1-28; Leopold Wenger, Canon in den römischen Rechtsquellen und in den Papyri: eine Wortstudie, Wien, 1942; „Über canon und regula in den römischen Rechtsquellen”, in Zeitschrift der Savigny-Stiftung für Rechtsgeschichte: Kanonistische Abteilung 32 (1943), pp. 495506; Herbert Oppel, Kovóv. Zur Bedeutungsgeschichte des Wortes und seiner lateinischen Entsprechungen (Regula-Norma), Leipzig, 1937; loan Cozma, „Cuvântul canon în terminologia bisericească. Sensul și folosirea lui în legislația canonică sinodală”,

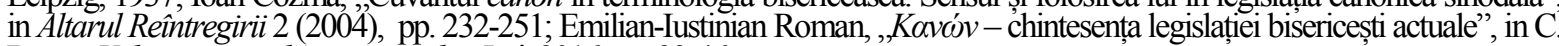
DRON, Valoarea actuala a canoanelor, Iasi, 2016, pp. $23-46$.

${ }_{3}^{3}$ Pierre Chantraine, Dictionnaire étymologique de la langue grecque. Histoire de mots, Paris, 1968, p. 493; Robert Beekes, Etymological Dictionary of Greek, vol. 1, Leiden, 2010, p. 637. For a presentation of the etymology of the term „,Kov'́v”, see: Răzvan Perșa, ,Sensurile termenului kavóv în Tradiția canonică a Bisericii Ortodoxe în primele patru secole”, in Astra Salvensis 4 (2016), nr. 7, pp. 20-39.

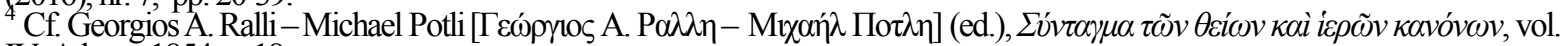
IV, Athens, 1854, p. 18.

5 Johan Lust-Erik Eynikel-Katrin Hauspie, A Greek-English Lexikon of Septuagint, Stuttgart, 2003, p. 642

${ }^{6}$ Sanctus Climentis, Epistola ad Corinthios, VII, 2 (PG I, col. 223-224).
} 
the totality of the normative order of the Church, the „sum of Church norms”, the ultimate standard or benchmark offered by the Gospel to inform the life of the Church; God's commandments and the apostles' prescriptions, passed down in the living tradition of the Church and providing the norms that underlie the life of the Church. The canon is the preexisting authority which synods and councils simply invoke and protect from distortions, confirming (not formulating) it as the ,ancient practice and custom" of the Church ${ }^{7}$.

With this connotation of "guideline" or ,normative prescription", the term kavóv was employed in Church language up to the $4^{\text {th }}$ century; throughout the first three centuries, rules governing the manner of living in compliance with the New Testament teachings were usually ascribed to the Holy Apostles (pseudo-epygraphic writings) and had a markedly consuetudinary character, as they derived from a custom (usus / mos / consuetudo $)^{8}$.

From early $4^{\text {th }}$ century onwards, the Church summoned Ecumenical Councils which passed

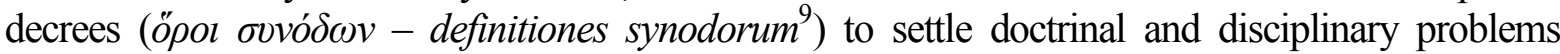
occurring in the Church life. Subsequently, in order to distinguish them from doctrinal rulings, the councils' decisions on disciplinary issues gradually began to be identified as $\kappa \alpha v o ́ v \varepsilon \varsigma$ - that is, concrete instantiations of the "Church's canon (moral normative)" ${ }^{\prime 10}$.

Although they had emerged in a society deeply indebted to the Roman law, conciliar decisions on disciplinary issues arising in Church life were not designated by the well-established term vó $\mu \varsigma$ or lex; from the earliest times, they were instead termed $\kappa \alpha v \omega ́ v$, a Greek term subsequently translated into Latin by regula, precisely in order to point to the difference between the nature of the Church and that of the State, respectively. Canons thus exist and are applied only within the Church, deriving their authority from the moral-religious assessment of one's acts, rather than the coercive force exerted by the State laws ${ }^{11}$. For this reason, probably, some authors regard the canon as the „churchly antonym” to the laws of State ${ }^{12}$.

From Latin, the term canon was borrowed by all Romanic languages, designating a pastoral rule issued by the ecclesiastical authority, sanctioned by a Council and acknowledged by consensus throughout the entire Church. With the same meaning, the term canon was also imported into the Germanic languages as kanon. In Slavonic language, the Greek term $\kappa \alpha v \omega ́ v$ was translated as правило (rule) and still retains this form and connotations in most Slavic languages. From Slavonic, the term pravila was introduced in Romanian language, meaning a decree or decision of either a secular or ecclesiastical nature, and since the $16^{\text {th }}$ century it has become established as designation for a collection of canons and/or laws ${ }^{13}$.

\section{THE HISTORY AND EVOLUTION OF THE SEMANTIC CONNOTATIONS ATTACHED TO THE TERM ,CANON” IN THE CHURCH}

Along the times, the term canon ( $\kappa \alpha v \omega ́ v)$ has undergone a significant semantic evolution in the ecclesiastical language, coming to define both the pastoral rule sanctioned by a council and received by the entire church, and the epithemia (the penance) imposed by a priest to a penant during

\footnotetext{
${ }_{8}^{7}$ Ioan Icăjr., Canonul Ortodoxiei. Canonul apostolic al primelor secole, Sibiu, 2008, p. 118.

${ }^{8}$ Cf. Petre Coman, ,Problema obiceiului de drept în sfintele canoane”, in Studii Teologice 21 (1969), no. 5-6, pp. 399-409; Samir Gholam, „Obiceiul ca izvor în dreptul romano-bizantin și în tradiția patristico-canonică a Bisericii Ortodoxe”, in Studii Teologice 27 (1975), no. 5-6, pp. 452-463.

${ }^{9}$ Evangelos Roussos, [Evóry

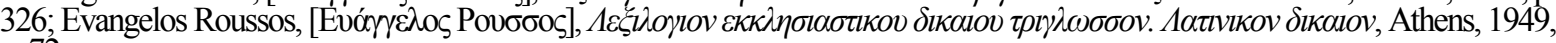
po 72 .

For an analysis of the term $\kappa \alpha v \omega$ w and its connotations in the synodal decisions of $4^{\text {th }}-9^{\text {th }}$ centuries, see: David Wagshal, Law and the legality in the Greek East: The Byzantine Canonical Tradition, 381-883, Oxford, 2015, pp. 139-141. See also: Jonathan

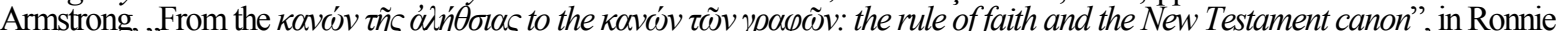
Rombs - Alexander Hwang (ed.), Tradition and the Rule of Faith in the Early Church: Essays in Honor of Joseph T. Lienhand S.J., Washington, 2010, pp. 30-47.

${ }_{11}^{11}$ Nicolae Dură, ,Dreptul și religia. Normele juridice și normele religios-morale”, in Analele Universității ,,Ovidius” 1 (2003), p. 20.

${ }_{12}$ Bruno Steimer, Vertex Traditionis. Die Gattung der altchristlichen Kirchenordnungen, Berlin - New York, 1992, p. 87.

${ }^{13}$ Cf. Ștefan G. Berechet, Legătura dintre Dreptul bizantin și românesc, vol. I, part I, Vaslui, 1937, pp. 90-140.
} 
the Holy Mystery of Confession, as well as the list of Bible books acknowledged as authentic. Therefore, it is necessary to elaborate on the semantic history and evolution of the term canon in the ecclesiastical language.

\section{a. A brief history of the term „canon" in Church language}

Since its very beginnings, the Christian Church - fully aware of its divine-human constitution - felt it necessary to establish specific rules and regulations, in order to systematize its own organization and operation. The New Testament texts denote the importance attached to the organization and smooth running of ecclesial communities, as well as the brotherly relationships among them. Subsequently, this concern developed gradually and unsystematically, in response to the pastoral needs that arose, and resulting in certain rules aimed at directing the members of the respective community towards union with Lord Jesus Christ.

During the first three centuries, Church was organized and operated in direct dependence on the attitude of the imperial authority towards the newly-emerged Christian communities. As long as the Roman authority did not impose any restrictions against Christians, the Church was able to organize itself and operate according to its own pastoral rules and in compliance with the Roman legislation ${ }^{14}$. Once the persecutions started, the Church had to conceal its corporate existence and could no longer work on its institutional organization. During these times of persecution from the Roman authority, the Church could not assume any stance as a public institution, since Christianity had been declared religio illicita across the Empire, and Christian communities were, consequently, considered to be collegia illicita ${ }^{15}$.

Pastoral rules addressing the organization and operation of the Church are mentioned, though not presented in a systematic manner, both in New Testament writings (mainly chapter XV in the Acts of the Apostles ${ }^{16}$ ), and in the pseudo-apostolic literature: the Didache (Teaching) of the Twelve Apostles, the Canons of Saint Hippolytus, Epitome Constitutionum Apostolorum, the Ordinances of the Holy Apostles Through Clement, Canones Apostolorum Ecclesiastici, the Apostolic Constitutions, or the Didascalia Apostolorum ${ }^{17}$. Although these latter writings - whose character was liturgical par excellence and had only a tangential disciplinary and organizational relevance enjoyed great popularity during the first Christian centuries, they were not universally accepted as rules officially acknowledged by the Church, and in the $7^{\text {th }}$ century they were rejected by a decree of the Trullan Council (canon 2).

In early $4^{\text {th }}$ century, through the Edict of Serdica issued in $311 \mathrm{AD}$, emperor Galerius (305311) ended the persecutions against Christians and returned to them the goods confiscated during the persecution of Diocletian (284-305) ${ }^{18}$. Through the Edict of Milan (Edictum Mediolanense), proclaimed by emperor Constantine the Great (306-337) in $313 \mathrm{AD}^{19}$, the Church was granted the

\footnotetext{
${ }^{14}$ Cf. Melchiorre Roberti, „Le associazioni funerarie cristiane e la proprietà ecclesiastica nei primi tre secoli”, in Studi dedicati alla memoria di Pier Paolo Zanzucchi, Milan, 1927, pp. 89-113.

${ }_{16} \mathrm{Cf}$. Giuseppe Bovini, La proprietà ecclesiastica e la condizione giuridica della Chiesa in età precostantiniana, Milan, 1949

${ }^{16}$ Cf. Constantin Preda, Credința si viața Bisericii primare. O analiză a Faptelor Apostolilor, Bucharest, 2002; Ioan Mircea, „2Organizarea Bisericii și viața primilor creștini după Faptele Apostolilor”, in Studii Teologice 7 (1955), no. 1-2, pp. $64-92$.

${ }^{17} \mathrm{Cf}$. Brian Edwin Ferme, Introduction to the History of the Sources of Canon Law. The Ancient Law up to the Decretum of Gratian, Montreal, 2007, pp. 29-50; Peter Erdö, Storia delle fonti del diritto canonico, Venice, 2008, pp. 17-29.

${ }_{19}$ Alberto Baraznò (ed.), Il cristianesimo nelle leggi di Roma imperiale, Milan, 1996, p. 149.

${ }^{19}$ The Edict of Mediolanum (today's Milano, Italy) is an administrative document issued by the Roman emperors Constantine and Licinius in April $313 \mathrm{AD}$, in the imperial palace of Mediolanum. It guaranteed religious tolerance across the Roman Empire, thus allowing Christians freedom of worship. It also stipulated the restitution of all buildings confiscated from Christians. Juridically, this document is a rescript, as it simply confirmed what had been already decreed by the Edict of Serdica. issued bv emneror Galerius on 30 Anril 311. The imnerial decree is known mainlv from the writings of bishon Eusebius of Cesarea. who in his Ecclesiastical Historv/ Historia Ecclesiastica (HE. X. 5. 2-14) translates a document nublished in Latin bv emneror Licinius in the nrovinces of Siria. Palestine and Egvnt after the death of Maximin Daia (Julv-August 313). In 1678. the French scholar Étienne Baluze (1630-1718) discovered the onlv extant manuscrint of De mortihus nersecutorum (DPM. XLVIII. 2-13). written bv the Christian anologete Lucius Caecilius Firmianus Lactantius and thus offered to the general readershin a Latin version of the Edict. issued bv the same Licinius at Nicomedia on 13 . June 313. Cf. Anastasio Cinriani. L'Editto di Milano e il suo valore noliticoreligioso, Rome, 1913. See also Nicolae Dură, „Edictul de la Milan (313) și impactul lui asupra relațiilor dintre Stat și Biserică.
} 
legal right to organize itself and to operate within the Roman Empire, being acknowledged as religio licita. Through the Edict of Thessalonica promulgated on $28^{\text {th }}$ of February, 380 by emperor Theodosius the Great (379-395), Christianity was declared the only religio licita (the official religion) of the Roman Empire, receiving full support from the political authority ${ }^{20}$. Freedom, peace, the favorable legislative framework, as well as the public support, allowed the Church to develop very much, especially in the direction of public worship and the organization of its administrative bodies ${ }^{21}$.

During the $4^{\text {th }}-5^{\text {th }}$ centuries, synods and councils were increasingly called for, in order to respond to concrete situations in the life of Christian communities; they issued numerous doctrinal and disciplinary decrees in this sense ${ }^{22}$. The disciplinary decisions were regarded by the Fathers convened in councils, as pastoral rules intended to regulate certain aspects in the organization and operation of the Church, with no claim to any juridical authority. In time, however, these pastoral rules came to be identified as canons (kavóves - canones) and in the Byzantine Empire, they even gained the authority of laws (lex - vouos) and were promulgated as such, alongside imperial laws aimed to regulate aspects in the life of the Church. A telling example is the decree issued in $545 \mathrm{AD}$ by emperor Justinian (527-565) in his Novela 131:

Sancimus igitur vicem legum obtinere sanctas ecclesiasticas regulas, quae a sanctis quattuor conciliis expositae sunt aut firmatae, hoc est in Nicaena trecentorum decem et octo et in Constantinopolitana sanctorum centum quinquaginta patrum et in Epheso Prima, in quo Nestorius est damnatus, et in Calcedone, in quo Eutychis cum Nestorio anathematizatus est. Praedictarum enim quattuor synodorum dogmata sicut sanctas scripturas accipimus et regulas sicut leges servamus ${ }^{23}$.

Thus in the $6^{\text {th }}$ century, the canons issued by the first four Ecumenical Councils were acknowledged as laws in the Byzantine Empire, and were applied and observed as such. This artificial equivalence created by the imperial authority, between Church canons and imperial laws facilited a significant influence of the Roman law on canon theology, and over time engendered confusions both concerning the Church-Empire relationship, and the organization and operation of the Church $^{24}$.

Câteva consideratii istorice. iuridice si ecleziologice". in Mitronolia Olteniei 64 (2012). no. 5-8. nn. 28-43: Giorgio Barone Adesi, „Libertà religiosa e convivenza delle religioni: nell'editto di Milano e negli indirizzi legislativi costantiniani”, in Ilaria Zuanazzi (ed.), Da Costantino à oggi. La libera convivenza delle religioni. Atti del Seminario interdisciplinare nel $1700^{\circ}$ anniverario dell'Editto di Milano organizzato dai Dottorati di ricerca in "Diritti e Istitutzioni" e in "Diritto, Persona e Mercato" del Dipartimento di Giurisprudenza dell'Università degli Studi di Torino (Torino, 24 ottobre 2013), Naples, 2015, pp. 11-40.

Cf. Jean Gaudemet, „L'Edit de Théssalonique: police locale ou déclaration de principe?”, in Henri W. Pleket - Arthur M. F. Verhoogt (ed.), Aspects of the Fourth Century A.D. Proceedings of the Symposium „Power and Possession. State, Society and Church in the Fourth Century A.D.", Leiden, 3-5 June 1993, Leiden, 1997, pp. 43-51; Dragos Boicu, „Teodosie cel Mare şi Edictul de la Tesalonic (28 februarie 380). Circumstanţe, comentariu, receptare", in Revista Teologică 94 '(2012), no. 2, pp. 186207. For details on this change in the juridical status of the Church in the Roman Empire, see Antonio Cardinale - Alessandro Verdelli, Il cristianesimo da culto proibito a religione dell'impero romano. La nascita del potere della Chiesa nel IV secolo d. C., Rome, 2010; Gian Luigi Falchi, „Legislazione e politica ecclesiastica nell'Impero romano dal 380 d.C. al Codice Teodosiano”, in Atti della Accademia Pontaniana VI (1986), pp. 179-212.

The body of literature on State-Church relationship during the $4^{\text {th }}$ century is extensive, thus we indicate here only a few representative writings addressing the Roman imperial legislative policy concerning the Church in the $4^{\text {th }}$ century: Antonella Di Mauro Todini, Aspetti della legislazione religiosa del IV secolo, Rome, 1990; Jean Gaudemet, „Politique ecclésiastique et législation religieuse après l'Edit de Théodose I de 380", in Atti dell'Accademia Romanistica Costantiniana 7 (1986), pp. 1-22.

${ }^{22}$ Cf. Nikos Maghioros, „Lineamenti della normativa conciliare canonica dal 313 al 425 ”, in Il diritto romano canonico quale diritto proprio delle comunità cristiane dell'Oriente mediterraneo. IX Colloquio internazionale romanistico canonistico, Città del Vaticano, 1994, pp. 365-453.

${ }^{23}$ Justinian, Novella 131.1. See also: Giorgio Barone Adesi, „Legittimazione e limiti di vigenza dell'ordinamento canonico nell'impero romano", in Gian Luigi Falchi - Antonio Iaccarino (ed.), Legittimazione e limiti degli ordinamenti giuridici. XIV Colloquio Giuridico Internazionale, Città del Vaticano, 2012, pp. 319-336.

${ }^{24}$ On the influences mutually exerted between Roman law and Christianity, see: Raymond Théodore Troplong, De l'influence du Christianisme sur le droit civil des romains, Paris, 1843; Périclès-Pierre Joannou, La législation impériale et la christianisation de l'Empire romain (311-476), Rome, 1972; Amilcar Alivizatos, ,Les rapports de la législation ecclésiastique de Justinien avec les canons de l'Eglise", in Atti del Congresso Internazionale di Diritto Romano (Bologna e Roma XVII-XXVII aprile MCMXXXIII), vol. II, Pavia, 1935, pp. 79-87; Jean Gaudemet, „Elementi giuridici romani nella formazione del diritto ecclesiastico dei primi secoli”, in Mondo classico e cristianesimo. Atti del convegno su Mondo greco-romano e cristianesimo, Roma 13-14 maggio 1980 , 
To be better preserved and more easily applied, the canons issued or sanctioned by the Ecumenical councils were put together in collections of canons or canon collections, which classified them mainly according to their chronological order. This did not only facilitate the preservation and dissemination of canons, but also expressed their pastoral importance, transcending the confines of both time and space. Later, from the $6^{\text {th }}$ century onwards, the canon collections began to include alongside canons, the imperial laws concerning the Church, thus creating a new type of collections: the nomocanons, with a definitive impact on the manner of collecting and passing down the holy canons in the Church $^{25}$.

In the aftermath of the last Ecumenical Council of $787 \mathrm{AD}$, a collection was compiled, sanctioned and acknowledged, including all the canons validated by the Church, collectively identified by the title ,the Holy Canons". Subsequently, these Holy Canons were added other ones, which despite not being sanctioned by any Ecumenical Council as official decrees, were however accepted and received unanimously by all autocephalous Churches ${ }^{26}$, by consensus Ecclesiae dispersae. Concerning this manner of adopting decisions within the Orthodox Church, when an ecumenical council does not have the possibility to convene, professor Valerian Șesan (1878-1940) explained that,

in relation to an ecumenical council, consensus Ecclesiae is a corollary completing the decision of an ecumenical council, or replacing it. If it is about an addition intended to complete it, then consensus Ecclesiae has the same authority as the ecumenical council. Consensus Ecclesiae is a body exerting the central authority in the Church. The difference lies in the following: through an ecumenical council, the decisions are made by the gathering of bishops; through consensus Ecclesiae, the bishops (episcopacy) issue the decisions, however not in a gathering, but as they are dispersed. [...] In practice, the decisions of this body exerting church power are reached as follows: the bishops of one Church address a circular letter to the protos among the bishops of each of the other Churches, presenting their opinion on a particular matter. If the rest of the bishops agree on the respective issue, then this common stance becomes mandatory for the entire Church $^{27}$.

Therefore, during its two millennia of historical existence, the Church has always made universally valid decisions in a synodal manner, either through the councils later acknowledged as ecumenical, thus universally authoritative $\left(4^{\text {th }}-8^{\text {th }}\right.$ centuries $)$, or through the consensus of the autocephalous Orthodox Churches, that is, the consensus Ecclesiae dispersae $\left(9^{\text {th }}-20^{\text {th }}\right.$ centuries). In this latter instantiation of the synodal manner of reaching decisions in the Church (consensus Ecclesiae dispersae), employed since the $9^{\text {th }}$ century to the present, there are two stages in the synodal decision-making process: first, at the level of one Orthodox Church, decisions are made by the synod of bishops; then, each autocephalous Orthodox Church expresses her,,vote" at panOrthodox level (that of the entire Orthodox Church) by means of synodal letters (encyclicals). Lack of consensus over a decision entails its annulment. In the second Christian millennium, by this synodal manner of deciding through the consensus of the autocephalous Orthodox Churches, decisions have been passed on many aspects of the utmost importance for the Church life, such as

Rome, 1982, pp. 171-182; Nikos Maghioros, La recezione della normativa conciliare nel diritto imperiale in materia di fede conservato nel Cth. XVI, Rome, 1998.

${ }_{25}$ For a historical presentation of the manuscript collections of canons during the first Christian millennium and the subsequent literature, see: Lotte Kéry, Canonical Collections of the Early Middle Ages (ca. 400-1140) . A Bibliographical Guide to the Manuscripts and Literature, Washington, 1999.

${ }^{26}$ Traditionally, the phrase "Church autocephaly" indicates in the Orthodox ecclesial language the canonic status of a local Church, which enjoys maximum autonomy and has the right to elect its own head ( $\pi \rho \tilde{\omega} \tau o \varsigma-$ primus) by the vote of its own Synod of bishops. Cf. Georgică Grigoriță, „Autocefalia în Biserica Ortodoxă. Studiu canonic”, in Autocefalia: libertate și demnitate, Bucharest, 2010, pp. 65-82.

${ }^{27}$ Valerian Sesan, Curs de Drept Bisericesc Universal (cu considerarea Dreptului bisericesc particular român), Cernăuți, 19361937, pp. 198, 199-200. 
acknowledging or not acknowledging the autocephaly of particular local Churches, and including new autocephalous Churches in the Diptychs.

Returning to the compilation of the single, common corpus canonum of the Church, we mention that in the $10^{\text {th }}$ century, the canons included in the collection known as the Nomocanon in 14 titles or the Nomocanon of Photius were acknowledged as having authority over the entire Church, by a decision of an Endemic Synod convened at Constantinople in 920 AD; the decision was subsequently accepted by consensus throughout the entire Church, and thus became universally valid. After the schism of 1054, these Holy Canons constituted a single, common corpus canonum of the Orthodox Church and were published, translated and commented upon in various languages ${ }^{28}$. In the canon collections of the Orthodox Church of the second Christian millennium, the authors added a number of canons issued by synods convened after the $8^{\text {th }}$ century, or by Holy Fathers (as in the case of the so-called ,,additional canons", intended to complete the former ones), even though these latter ones were not universally implemented across the entire Church. Thus, each collection of church canons, dating from the second Christian millennium, has its own particular contents.

\section{b. The importance and applicability of the holy canons in the Church}

Throughout the times, especially since the 19th century, Orthodox theologians and canonists have expressed their views on the value, role and importance of the holy canons in the Orthodox Church. Such opinions ranked from granting canons a fundamental position the life of the Church, to regarding them as utterly obsolete. In the $20^{\text {th }}$ century, quite frequently the Orthodox theologians tended to borrow or imitate Western practices or views on the role, importance and practical manner of implementing the holy canons in everyday ecclesial life, mainly by recommending to imitate the undertaking of the Roman-Catholic Church, which in 1917 published its first Code of Canon Law (Codex Iuris Canonici) $)^{29}$.

More precisely, after 1917, under the influence of the process of canon codification initiated by the Roman-Catholic Church, some Orthodox theologians asserted that the holy canons were outdated and obsolete, therefore the Orthodoxy needed in their opinion to engage in a process of canon codification, with a view to adopting a single, unified „code of canon law" to take effect and be observed throughout the entire Orthodox Church. Their argument was usually the alleged impossibility of a positive development of Orthodox canon law, caused by the immutability of the holy canons. The matter of the importance of the holy canons for the Church, as well as the proposal to codify them, were addressed by the first international congress of Orthodox theology held in Athens in $1936^{30}$, when the Romanian professor Valerian Șesan (1878-1940) delivered a lecture presenting the importance of the holy canons for the Church and the lack of real grounds for a possible codification according to the Catholic model ${ }^{31}$.

During the second half of the $20^{\text {th }}$ century, the tenet of the codification of holy canons (put forth by some Greek theologians), was adhered to even by the current Ecumenical Patriarch -

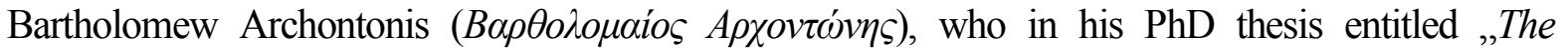

\footnotetext{
${ }^{28}$ Cf. † Nicodim Milaș, Drept bisericesc oriental, Bucharest, 1915, pp. 65-92; Ioan N. Floca, Drept canonic ortodox. Legislatie și administratie bisericească, vol. I, Bucharest, 1990, pp. 75-76; Vlasios Phidas, Droit canon. Une perspective orthodoxe, Chambésy, 1998, pp. 23-24; Spyros Troianos, „Byzantine Canon Law to 1100”, in Wilfried Hartmann - Kenneth Pennington (ed.), The History of Byzantine and Eastern Canon Law to 1500, Washington, 2012, pp. 138-141. See also: John Erickson, „The Orthodox Canonical Tradition", in Saint Vladimir's Theological Quarterly 27 (1983), pp. 155-167.

In the Roman-Catholic Church, the first Code of Canon Law (Codex Iuris Canonici) was promulgated by Pope Benedict XIV on 27 May 1917, by the apostolic constitution, ,Providentissima Mater Ecclesiae”.

${ }^{30}$ For the entire debate, see: Constantin Dron, Valoarea actuală a canoanelor Bucharest, 1928 (republished in 2016 at Iasi by Emilian Iustinian Roman); Liviu Stan, „Codificarea canoanelor”, in Studii Teologice 12 (1960), no. 7-8, pp. 627-648; „, Tăria nezdruncinată a sfintelor canoane”, in Ortodoxia 22 (1970), pp. 300-304; Nicolas Afanassieff,, „The Canons of the Church: Changeable or Unchangeable?", in Saint Vladimir's Theological Quarterly 11 (1967), pp. 54-58; Panagiotis Boumis, „To кupos

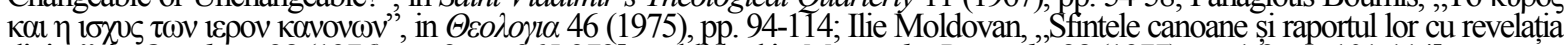
divină, in Ortodoxia 28 (1976), no. 2, pp. 365-373[republished in Mitropolia Banatului 28 (1977), no. 1-3, pp. 101-114].

${ }^{31}$ Valerian Şesan, ,Revizuirea canoanelor şi a altor norme bisericeşti, precum şi codificarea lor”, in Candela 47 (1936), pp. 145-159.
} 
Codification of the Holy Canons and the Canonical Constitutions in the Orthodox Church" (defended in 1968 at the Pontifical Oriental Institute in Rome, under the supervision of professor Ivan Žužek), proposed that this envisaged ,code of canons" should be written in Greek ${ }^{32}$ (sic!). Also, the $\mathrm{PhD}$ supervisor of the Greek hierarch - the Slovenian Jesuit Ivan Žužek (1924-2004), also published in the year 1969 a study advocating for the idea of a codification of the Holy Canons in the Orthodox Church ${ }^{33}$. The same proposal was reiterated by Bartholomew Archontinis during the first meeting of the Society for the Law of the Eastern Churches, which took place in 1971 at Vienna ${ }^{34}$.

In 2015, the Greek archimandrite Grigorios Papathomas attempted to put into practice this idea of codifying the holy canons, by publishing a bilingual (Greek-French) volume, in which he included in a peculiar manner the texts of all writings he deemed to be canons, marking them with consecutive numbers. Thus the collection compiled by archimandrite Papathomas includes 771 „canons", the first one being a New Testament excerpt, namely the Acts of the Apostles 15, 23-29 (sic!), and the last one - canon 3 issued by the Council of Constantinople of $879 / 880 \mathrm{AD}^{35}$. Beside the fact that by issuing this volume, the Greek professor appears to assume the position of a pan-Orthodox authority, higher than the Councils, by deciding on an arbitrarily compiled corpus of canons, we must note the fact that currently there is no critical edition of the text of the holy canons, and no panOrthodox consensus over a collection of canons in effect throughout the entire Orthodox Church.

The Father professor Liviu Stan (1910-1973) was the first Orthodox canonist to provide a systematic, pertinent response to this initiative pursuing the codification of canons: in 1954 he published a study ${ }^{36}$ where he pointed out that according to the Orthodox canon doctrine, the holy canons are neither outdated, nor obsolete, but on the contrary they contain all the fundamental principles underlying the organization and operation of the Church. Therefore, the holy canons are not to be interpreted or applied word for word, but rather by identifying the fundamental principles they contain and by putting these principles into practice in Church life.

Subsequently, during the official ceremony awarding him the title of Doctor Honoris Causa from the part of Aristotle University of Thessaloniki (Greece) on 7 May, 1968 the Romanian canonist chose to deliver a lecture entitled „On the fundamental canonical principles of the Orthodoxy",37. This was intended

not as a justification against the accusers, but mainly aiming to present as clearly as possible, from the canonical point of view, the life of the Orthodox Church, to the vocal opponents who attack these principles, and especially attack our perseverence in preserving and safeguarding the fundamental elements of its essence ${ }^{38}$.

In his paper, Father professor Liviu Stan stated that,

generally, the fundamental canonical principles of Orthodoxy are contained, on the one hand, in the universal constitutional charter of the Church, namely the collection of the Holy Canons, and

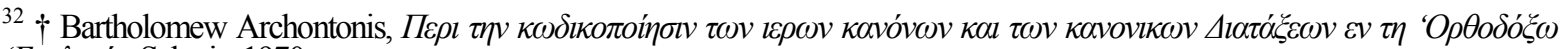

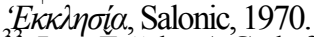

33 Ivan Žužek, ,A Code for the Orthodox Churches”, in Concilium 8 (1969), pp. 74-79.

$34+$ Bartholomew Archontonis, ,A Common Code for Orthodox Churches", in Kanon 1 (1973), pp. 45-53.

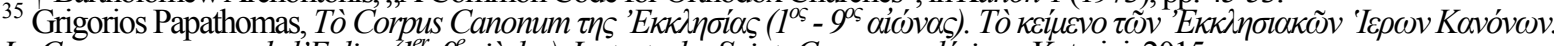
Le Corpus canonum de l'Eglise (1 $1^{e r}-9^{e}$ siècles). Le texte des Saints Canons ecclésiaux, Katerini, 2015.

${ }_{37}$ Liviu Stan, ,Legislatia bisericească și valoarea ei canonică”, in Mitropolia Olteniei 6 (1954), no. 11-12, pp. 598-617.

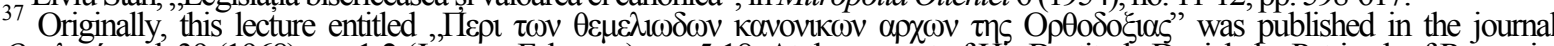

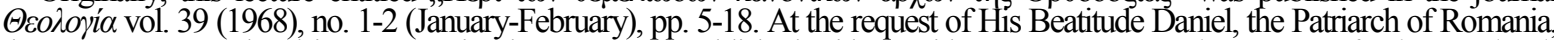
the paper was translated into Romanian language and published with the title ,Despre principiile canonice fundamentale ale Ortodoxiel" in the volume Autocefalia. Libertate si demnitate, Bucharest, 2010, pp. 18-25. The translation was also published in Revista Teologică 20 (2010), no. 3, pp. 175-185. Most likely, the idea of Father professor Liviu Stan of providing a systematic presentation of the principles contained in the text of the holy canons, had been inspired among others by the book authored by Panagiotis Bratsiotis (1889-1980) entitled ,Die Grundprinzipien und Hauptmerkmale der Orthodoxen Kirche”, published in 1938 (Panagiotis Bratsiotis, Die Grundprinzipien und Hauptmerkmale der Orthodoxen Kirche, Athens, 1938) and by the book authored by Ilya Stepanovich Berdnikov (1839-1915) entitled „The basic principles of the Ecclesiastical Law of the Orthodox Church” (Илья Степанович Бердников, Основнье начала церковного права Православной Церкви, Kazan, 1902) published in 1902.

${ }^{38}$ Liviu Stan, ,Despre principiile canonice fundamentale ale Ortodoxiei”, p. 18.
} 
on the other hand in the long-standing, constant consuetudinary practice of Church life established as customs underlying the canon law. Some of these principles have dogmatic contents or grounds, not only a juridical or canonical basis. Thus, according to their contents we can divide them into two categories. The first category includes the fundamental canonical principles with dogmatic contents or grounds: 1. the ecclesiological-institutional principle, 2. the organic (constitutional-ecclesiastic) principle, 3. the principle of ecumenicity, 4. the hierarchical principle, 5. the synodal principle, 6. the principle of economy, 7. the principle of external autonomy, 8. the principle of loyalty to the State. The second category includes the following fundamental canonical principles having a juridical basis: 1 . the principle of autocephaly, 2. the principle of internal autonomy, 3. the nomocanonic principle, 4 . the territorial principle ${ }^{39}$.

The Romanian canonist adds that further principles may be added, and they can also be systematized differently. Having enumerated these principles, Father professor Liviu Stan points out that, an overall assessment of the fundamental canonical principles of Orthodoxy sees them as the firm, unbreakable standards of the Church, which contribute within the institution and activity of the Church, to securing the necessary balance - which could hardly be struck by any other human institution ${ }^{40}$.

For a concrete illustration of the manner in which the fundamental canonical principles are applied in the life of an autocephalous Church, the canonist born in Hunedoara provided a thorough, comprehensive analysis of the way in which they were reflected in the 1948 Statutes for the Organization and Operation of the Romanian Orthodox Church as well as its Regulations ${ }^{41}$.

Moreover, in the year 1969, Father professor Liviu Stan published a study ${ }^{42}$ making a stand against the envisaged codification of the holy canons, which he described as completely alien to the Tradition of the Church. The Romanian canonist also made it clear in his writings that the holy canons are operative theoughout the entire Orthodox Church and that they can be amended, modified or replaced only by an Ecumenical Council - the supreme authority of the Orthodoxy ${ }^{43}$.

Subsequently, other Orthodox theologians and canonists elaborated on this ecclesiological perspective of Father professor Liviu Stan, addressing the role and importance of the holy canons at present, as well as their current practical applications in the organization and operation of the Orthodox Church ${ }^{44}$; they included in the canon theology textbooks, and in their studies, the concept of canonical principles fundamental for the organization and operation of the Orthodox Church ${ }^{45}$. Professor Iorgu Ivan (1899-2001) explained that:

These principles of organization and management are called fundamental, because they were established from the very beginnings, in light of the teachings of our Saviour Jesus Christ, like firm pillars supporting the organization of the Church, together with the dogmas and the moral

\footnotetext{
${ }_{40}^{39}$ Liviu Stan ,Despre principiile canonice fundamentale ale Ortodoxiei”, p. 18.

${ }_{41}^{40}$ Liviu Stan, ,Despre principiile canonice fundamentale ale Ortodoxiei”, p. 25.

${ }^{41}$ Liviu Stan, „Legislația Bisericii Ortodoxe Române în timpul arhipăstoririi Preafericitului Părinte Patriarh Justinian. Principiile canonice de bază ale Ortodoxiei oglindite în legislatia Bisericii Ortodoxe Române", in Ortodoxia 20 (1968), no. 2 , pp. $267-296$.

42 Liviu Stan, „Codificarea canoanelor”, pp. 627-64்.

${ }_{43}^{43}$ Cf. Liviu Stan, ,Tăria nezdruncinată a sfintelor canoane”, pp. 300-304.

44 Irimie Marga, „Actualitatea sfintelor canoane”, in Revista Teologică 12 (2002), no. 3, pp. 41-46.

${ }^{45}$ Iorgu Ivan, ,Principii de organizatie și disciplină bisericească în canoanele Sinodului al IV-lea ecumenic", in Telegraful Român 100 (1952), no. 7-8, pp. 2-4; Ion-Gheorghe Rușescu, „Principii și dispozitii de organizare și disciplină în canoanele Sinodului VI ecumenic", in Studii Teologice 35 (1983), no. 1-2, pp. 64-78े; Liviu-Ćlaudiu Moisiu, „Principii de organizare și disciplină bisericească în canoanele Sinodului III ecumenic”, in Studii Teologice 36 (1984), no. 9-10, pp. 656-666; Constantin Rus, ,Principii de organizare și disciplină bisericească în canoanele Sinodului VII ecumenic de la Niceea din anul 787', in Mitropolia Banatului 37 (1987), no. 2, pp. 40-57; Nicolae Dură, ,Principiile canonice, fundamentale, de organizare şi functionare a Bisericii Ortodoxe si reflectarea lor în legislaţia Bisericii Ortodoxe Române", in Mărturie Ortodoxă 6 (1987), pp. 127-144 [republished in Revista de Teologie Sfântul Apostol Andrei 5 (2001), pp. 129-140]; Ioan N. Floca, Drept canonic ortodox, vol. I, pp. 191-205; Constantin Rus (ed.), The place of Canonical Principles in the Organization and Working of Autocephalous Orthodox Churches. The Canon Law International Symposium (Arad, 10-12 September 2008), Arad, 2008; Iulian Mihai L. Constantinescu, „Principiile canonice fundamentale și aplicarea formei canonice in organizarea și conducerea Bisericii”, in Mitropolia Olteniei 67 (2015), no. 1-4, pp. 178-196.
} 
norms; they are also called canonical because, after uninterrupted usage they became established by means of the norms - termed canons - which the Holy Fathers of the Ecumenical Councils decreed or confirmed, as mandatory rules to be observed by the entire Church. ${ }^{46}$

However, the lack of pan-Orthodox consensus over the validity of the holy canons and the concrete manner of applying them in the ecclesial life, has created tensions within the Orthodox Church, especially over the matters of primacy and autocephaly, which generated theological disputes or de facto situations that did not comply with the canon stipulations. Some of these issues had an impact on the official theological dialogue between the Orthodox and the Roman-Catholic Churches, thus creating the image of Orthodoxy lacking unity ${ }^{47}$.

Finally, we note that the tensions recently created within the Orthodox Church by the different interpretation of a number of canons, have prompted certain authors to question the efficiency and necessity of applying the holy canons in Church life. This fact, as well as the lack of an unanimously acknowledged text of the holy canons, based on a critical edition, has allowed some authors to put forth various innovative proposals aimed at the codification, or even the alteration of the holy canons. All these facts, therefore, are a substantial motivation for drafting a critical edition of the text of the holy canons, to provide the basis for a unitary collection of canons valid for the entire Orthodox Church.

\section{c. The Canon - as a pastoral rule sanctioned by a Council and received by the entire Church}

With regard to the point in time when the term $\kappa \alpha v \omega$ v (designating a Council's decision concerning Church discipline or a pastoral rule) joined the ecclesiastic idiom, scholars currently hold several opinions.

Some historians investigating the sources of canon theology assert that the oldest mention in this sense, can be found in canon 14 of the Synod of Ancyra (314 AD). Other scholars maintain that the term $\kappa \alpha v \omega ́ v$ in its current meaning was first employed at the Ecumenical Council of Nicea (325 $\mathrm{AD}$ ), whose canons mention other previous canons, namely: canon 1 mentions apostolic canon 21 , as argument for admitting eunuchs into the clergy; canon 2 mentions the observance of apostolic canon 80 in the ordination of priests; canon 5 reiterates the stipulations of apostolic canons 12, 13, 32 and 37 on receiving the excommunicated persons into the Church, and the obligation for bishops' synods to convene at least twice a year; canons 9 and 10 maintain the stipulations of apostolic canons 25, 61 and 62 regarding the impediments to ordination; canons 15 and 16 mention apostolic canons 14 and 15 concerning the rule forbidding clergymen to be transferred; canon 17 reiterates the stipulations of apostolic canon 44 forbidding clergy members to engage in usury; canon 18 explains the stipulations of apostolic canon 39 governing the relationships among the members of the divinely-instituted hierarchy ${ }^{48}$.

Other authors assert that in the text of the Synod of Ancyra (314 AD), as well as the decrees issued by the First Ecumenical Council (325 AD), the term $\kappa \alpha v \omega$ v did not designate a rule already prescribed by Church authority, but the rule of the faith translated in fundamental principles of Christian life; therefore, the first official use of the term $\kappa \alpha v \omega$ s, to indicate a Council's decision

\footnotetext{
${ }^{46}$ Iorgu Ivan, „Importanţa principiilor fundamentale canonice de organizaţie şi administraţie, pentru unitatea Bisericii”, in Mitropolia Moldovei şi Sucevei 45 (1969), p. 155.

${ }^{47}$ See Georgică Grigorităă, ,Intâietate și sinodalitate în dialogul teologic oficial dintre Biserica Ortodoxă și Biserica RomanoCatolică. Studiu canonic”, in Ortodoxia 7 (2015), no. 1, pp. 104-177; „Streitfragen im Dialog zwischen der Orthodoxen Kirche und der Romisch-Katholischen Kirche”, in Dan Dungaciu (ed.), Sieben Hauptthemen für Rumänien im Jahr 2014, Bucharest, 2015 , pp. 709-725.

${ }_{48}$ Cf. Heinz Ohme, Kanon ekklesiastikos, pp. 24-114; Peter Erdö, ,Quid significat ,lex” in iure canonico antiquitatis (saecula IIIIV)", in Periodica 76 (1987), pp. 381-412; Heinz Ohme, ,Der Kanon-Begriff der Synode von Nizäia (325)”, in Studia Patristica 29 (1997), pp. 310-315; Constantin Rus, ,Canoanele Bisericii și funcția lor ecleziologică”, in Altarul Banatului 11 (2000), no. 7-9, pp. 37-46.
} 
regarding Church discipline, can be found as late as the epistle preceding the 25 canons of the Synod of Antioch, $341 \mathrm{AD}^{49}$.

We conclude that, although the experts do not agree on the exact date when the term кavóv was officially introduced in the ecclesiastical idiom, it is certain that already in the first half of the $4^{\text {th }}$ century, the term $\kappa \alpha v \omega ́ v$ officialy joined Church terminology to indicate the conciliar decrees received by the Church in matters of ecclesial discipline. Ever since, in the ecclesiastical language, the term canon defines (as its main meaning) a pastoral rule issued by a Church authority, a rule subsequently approved by a council and consensually accepted by the entire Church.

\section{d. The canon - as epithemia (penance) assigned by the confessor priest}

However, some $4^{\text {th }}$-century Church Fathers also employed the term $\kappa \alpha v \omega$ v to identify other activities in the life of the Church. For instance, Saint Basil the Great (330-379), in his epistles (containing the 96 canons ascribed to him) used the term $\kappa \alpha v \omega v v$ to designate the duration of the public penance which a Christian had to undertake after having confessed his/her sins in the Mystery of Confession $^{50}$. The current Orthodox theological language, however, names the time of penance

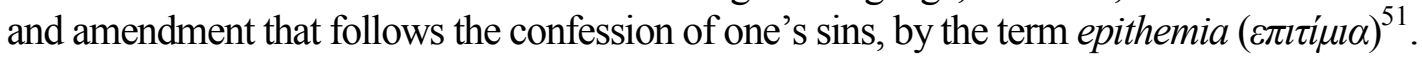

We also note that the Christian Church has set two categories of measures aiming to bring her erring members on the right path: epithemia (acts of penance) and punitive measures. The epithemia have an exclusively private character and are assigned to the faithful by the confessor priest, under the Holy Mystery of Confession, while the punitive measures have a publiccommunional character, and are applied by the canonical authorities of the Church, following an enquiry.

In conclusion, since the epithemia are not punishments or penalties, nor acts of ,satisfaction" rendered for the sins one has committed, but they aim to heal spiritually, to the greatest possible extent, the persons having strayed and to bring them to heartfelt repentance in order to enable them to regain communion with Christ, obviously the use of the term canon in the sense of epithemia is mainly due to the fact that theologically speaking, the epithemia have a similar meaning as canons, the difference lying only in the authority issuing them.

\section{e. The canon - as a list of Bible books}

In addition, we mention that from the $4^{\text {th }}$ century onwards, the list of Bible books acknowledged as the true Scriptures has been identified by the term $\kappa \alpha v \omega ́ v$, specialized language adopting the phrase „biblical canon". Thus since the early Christian age, those books which the Church accepted as inspired by the Holy Spirit and as sources of the divine Revelation, that is, acknowledged by the Church authorities as part of the Holy Scripture, were deemed to be canonical - in other words, included in the official list identified as the „biblical canon" since it had been sanctioned through a decree (canon). This list was compiled gradually, and was completed only in late $4^{\text {th }}$ century ${ }^{52}$.

\footnotetext{
${ }^{49}$ Cf. Ivan Žužek, „Sacralità e dimensione umana dei canones”, in Silvano Agrestini - Danilo Ceccarelli Morolli (ed.), Ius ecclesiarum vehiculum caritatis. Atti del simposio internazionale per il decennale dell'entrata in vigore del Codex Canonum Ecclesiarum Orientalium, Città del Vaticano 19-23 novembre 2001, Città del Vaticano, 2004, pp. 53-116; Ioan Ică jr., Canonul Ortodoxiei, pp. 117-120.

${ }_{50}$ Cf. can. 11 I Ecum., 4, 5 and 6 Ancyra, 2 and19 Laodicea, 11 Gregory of Neocaesarea, 22 and 75 Basil the Great.

${ }^{51}$ For the atonement of sinners, the Christian Church has set various corrections, generally classified into two categories: epihemia and punitive measures. Epithemia are applied to the faithful under the Holy Mystery of Confession, whereas the punitive measures are enforced by the canonical authorities of the Church. Cf. Dimitrios Papathanassiou Ghinis, Théologie et pastorale des pénitences (epitimia) selon l'Eglise orthodoxe, Strasbourg, 1981; Alexandru-Armand Munteanu, „Aplicarea epitimillor în lumina sfintelor canoane”, in Studii Teologice 13 (1961), pp. 445-465; Grigore Pătrulescu, ,Epitimiile canonice și ascetice în general”, in Studii Teologice 32 (1980), pp. 535-550.

${ }^{32}$ Heinz Ohme. Kanon ekklesiastikos. nn. 37-44. See also: Frederick Fvvie Bruce. The Canon of the Scrinture. Downers CroveIllinois. 1988: Andrés Sáez Gutiérrez. Canon v autoridad en los dos primeros siglos. Estudio histórico-teológico acerca de la relación entre la Tradición y los escritos apostólicos, Rome, 2014.
} 
Apostolic Canon 85 recommended to the faithful the biblical books whose reading was beneficial, so that they might avoid the apocryphal books mentioned in the apostolic canon 60 . The Synod of Laodicea (343 AD), indicated in its canon 60 biblical books that could be read in the Church, namely 22 Old Testament books and all New Testament books, except for the Book of Revelation, which most likely was still unknown at the time in Phrygia. Canon 24 of the Synod of Carthage (419 AD) enumerated the Old Testament books that could be read in the Church. Saint Athanasius the Great ( $† 373)$ also indicated the canonical books of the Biblie, mentioning that ,there are also other books, but they are not part of the canon; however the Holy Fathers recommend them for reading by those recently converted, who wish to learn about the Orthodox worship" (can. 2) ${ }^{53}$. Saint Gregory of Nazianzus indicated the list of the Old Testament and the New Testament books accepted during his times (can. 1). In his turn, Saint Amphilochius of Iconium enumerated in his own canon the canonical books of the Holy Scripture, and concluded by stating that ,this very true and correct canon ( $\alpha \psi \varepsilon v \delta \delta \dot{\delta} \sigma \alpha \tau o \varsigma \kappa \alpha v \grave{\omega} v$ ) contains the Scriptures inspired by God" (can. 1) ${ }^{54}$. Thus, the collection of Bible books acknowledged as authentic and authoritative in the Church has been identified as the „,canon" or ,biblical canon" since it was defined by the canons ${ }^{55}$. It is a telling fact that the oldest extant manuscript, containing such a list of the New Testament books, has been named the ,Muratori canon" after the name of its finder - Ludovico Antonio Muratori (1672-1750) ${ }^{56}$.

In the current Church language, the phrase „biblical canon” indicates the list of the Bible books accepted as authentic and authoritative. In the Orthodox Church, the phrase „biblical canon” defines the list of Bible books, which the Church has accepted as written under the inspiration of the Holy Spirit and containing the divine revelation. The Orthodox biblical canon includes 39 canonical books, and 14 anagignoscomena (books which are useful and worth reading) of the Old Testament as well as 27 canonical books of the New Testament ${ }^{57}$.

\section{f. The Canon - as a list of the Church Saints}

Since its very beginnings, the Church would include in a list of saints those whom it regarded as champions of the faith, and who had passed away. They were venerated, based on the dogmatic doctrine, by being remembered and by addressing them prayers, in their capacity as helpers and intercessors for the mercy of God. Originally, these lists of saints, written by every local community, included only the martyrs, which is why the respective lists were termed martyrologies or acts of the martyrs (acta sanctorum).

Later on, after the times of the persecutions, these lists of saints began to include some deceased Christians who had stood out during their lifetimes, by confessing and defending the Orthodox faith. Based on these local lists of saints, gradually a general catalogue of the Church saints was produced; it was known as the „saints' canon”. The process of including a new saint in the catalogue of Church saints, was identified by the verb , to canonize" derived from this phrase, and the result of this action has been termed ,canonization ${ }^{, 58}$.

\section{g. The Canon - as Eucharistic prayer}

\footnotetext{
${ }^{53}$ For details, see: David Brakke, ,Canon Formation and Social Conflict in Fourth-Century Egypt: Athanasius of Alexandria's Thirty-Ninth Festal Letter", in The Harvard Theological Review 87 (1994), no. 4, pp. 395-419.

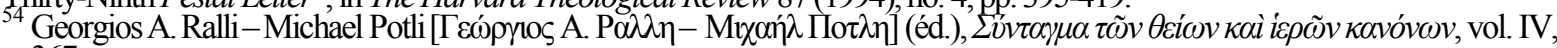
$\mathrm{p}_{5} 367$.

${ }_{56}^{5}$ For details, see: Constantin Rus, Canonul cărților Sfintei Scripturi după canoanele Bisericii Ortodoxe, Arad, 2001.

${ }^{56}$ Albert C. Sundberg Jr., „Canon Muratori: A Fourth-Century List”, in The Harvard Theological Review 66 (1973), no. 1, pp. 141.

${ }_{57}$ For details, see: Vasile Mihoc, „Canonul și inspirația Sfintei Scripturi văzute din punct de vedere orthodox”, in Ortodoxia 41 (1989), no. 3, pp. 20-30 [republished in Ortodoxia 48'(1997), no. 1-2, pp. 23-33]; Stelian Tofană, Introducere in Noul Testament: Test și Canon, vol. 1, Cluj Napoca, 1997, pp. 53-86.

${ }^{8}$ For details, see: Liviu Stan, „Despre canonizarea sfintilor în Biserica Ortodoxă”, in Ortodoxia 2 (1950), pp. 260-278; „Canonizarea sfinților după învățătura și după rânduielile 'Ortodoxiei”, in Mitropolia Olteniei 20 (1968), pp. 360-368; † Job "Getcha, „La canonisation des saints dans l'Eglise orthodoxe”, in Esprit et vie 115 (2004), pp. 34-38.
} 
In the liturgical idiom, especially that of Romanic languages, the term canon has been associated to the most important part of the Holy Liturgy - the Eucharistic prayer; thus the phrase

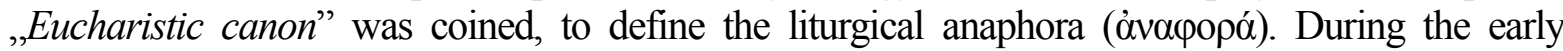
centuries of the Latin Christianity, the Eucharist itself was deemed to be Liturgy canon (canon missae $)^{59}$. Later, the Eucharistic prayers within the Holy Liturgy have been designated as the „Eucharistic canon”, in the West, and the ,anaphora”, in the East.

This phrase „Eucharistic canon" is not widely used in the specialized Orthodox terminology, which prefers the term ,anaphora”. In the current Catholic theological idiom, the phrase „Eucharistic canon" is employed to designate the central part of the Latin mass, which includes the Eucharistic prayers. The Latin Eucharistic canon is generally considered to originate from Egypt's Alexandrian tradition, but some of its elements also evince influences of the Antiochian tradition. The exact time when the Latin Eucharistic canon was created has not been ascertained, although authors assert there are attestations to it dating from the $3^{\text {rd }}$ century. However, it is known that its text was completed during the $13^{\text {th }}$ century, in Rome. This is probably why the Latin Eucharistic canon is currently known as the ,Roman canon" ${ }^{\circ 0}$.

\section{h. The Canon - as a poetic hymn of Christian worship}

In the Orthodox worship, the term canon generally designates a Christian religious poetic hymn, based on the Bible. The greatest number of such canons can be found in the service of the Orthros; however such canons are also included in the Apodeipnon (Compline), the Sunday Midnight Office, some Holy Mysteries (e.g. the Unction), hierurgies (the funeral service), as well as the celebration of the Holy Liturgy (the third and sixth chants).

Within the corpus of Christian hymnography, the canon is a composition comprising several hymns (odes, troparia, katabasia), which follow certain rules with regard to their form and their interconnections, so that together they form a whole. Historically, this type of hymn known as canon, dates from the $7^{\text {th }}$ century; it was created by Saint Andrew of Crete $(\uparrow 740)$, the author of the Great Penitential Canon chanted during the Lent. Over the following centuries, this hymn was developed and promoted by the Church, becoming a fixed part of the structure of religious services.

Generally, liturgical theology indicates a number of nine odes in order for a canon to be complete, but it also accepts shorter versions of the canon - with only two or three odes. In its turn, an ode comprises three to nine troparia, which all follow the structure of the first troparion (in terms of the number of syllables, and the stressed ones) - that is, the structure of the first stanza in the ode, which thus provides the model for the following stanzas' melodic line and number of lines and syllables. Within the corpus of Christian hymnography, the canon is the most elaborate form of Christian liturgical poetry: it is a unit containing nine chants (odes) comprising three or more stanzas each. Thus the components of a canon obey clear rules that dictate both their form, and their contents, and are united by a common topic. Therefore in the Orthodox worship, a canon is a hymn whose structure follows precise rules. Most likely, this structure created by clear rules was the reason why this type of Christian hymn has received the name canon. Thus in the Orthodox Church,

... the canon is the second and last lofty form of Byzantine poetry; it started to prevail over the kontakion during the $8^{\text {th }}$ century and continues to do so to this day ${ }^{61}$.

The term canon has also been associated with prayer, defining personal praying done according to certain prescriptions, concerning both its form and its contents; thus the phrase ,prayer

\footnotetext{
${ }_{60}^{59}$ Cf. Paul Cagin, L'Eucharistia, canon primitif de la messe ou formulaire essentiel et premier de toutes les liturgies ?, Paris, 1912.

${ }^{60}$ For details on the Roman canon, see: Félix María Arocena Solano, „En torno al canon romano”, in Burgense 36 (1995), no. 2 , pp. 393-425; Francisco Sanchez Abellan, ,Canon Romano”, in Helmántica 25 (1974), pp. 245-319.

Konstantin Nikolakopoulos, Imnografia ortodoxă la inceput și astăzi. Dicționar de termini liturgici și imnologici, Bucharest, 2015, p. 86.
} 
canon" (meaning a rule of prayer) was coined. In this case, there are no norms concerning the tone or quality of the recitation.

\section{THE RELATIONSHIP BETWEEN CHURCH CANONS AND STATE LAWS \\ a. Canons: pastoral rules of the Church}

The Christian Church, ever since the $4^{\text {th }}$ century, has operated a clear distinction between canons (кavóves - canones) ${ }^{62}$ and laws (vó $\mu \mathrm{or}-$ leges) ${ }^{63}$, especially visible in the Novels (Novellae) $^{64}$ issued by emperor Justinian $(527-565)^{65}$ and in the mixed collections (nomocanons). Currently this distinction, which Orthodox ecclesiology makes between canons

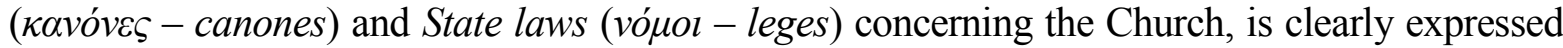

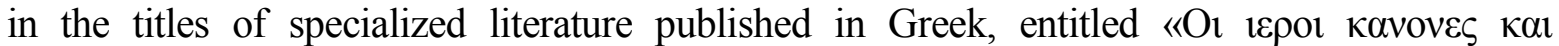

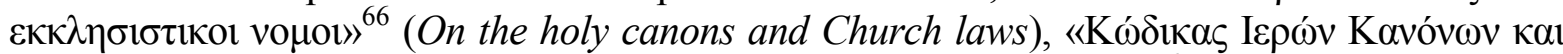

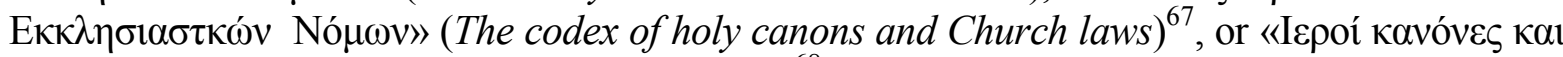

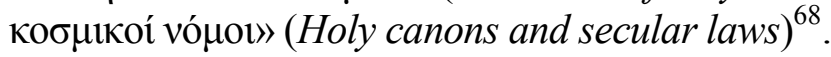

We note that, alongside the holy canons with authority over the entire Orthodox world, there are also civil laws which do not belong to this corpus canonum Ecclesiae orthodoxae, but concern the life and activity of the Church in the states where it is organized and operates. All these laws, most of them of administrative nature, are named ,nomoi" (vouoi - leges) ${ }^{69}$ in the first-millennium collections. The favorable attitude towards the Church of the Roman emperors, beginning with Constantine the Great, entailed a mutual influence between Christianity and the Roman law in effect at the time ${ }^{70}$. Thus, in the Roman Empire, the Christian Church was at first accepted politically (311 AD), then acknowledged legally (313 AD), and later privileged by the political authorities (380 AD). In this context, Church canons acquired increasing importance within the Roman Empire, so much so that in the $6^{\text {th }}$ century, emperor Justinian conferred the existing canons the authority of law

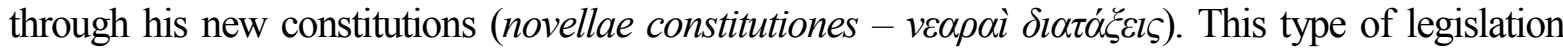

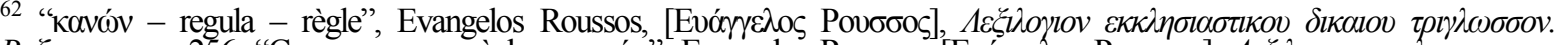

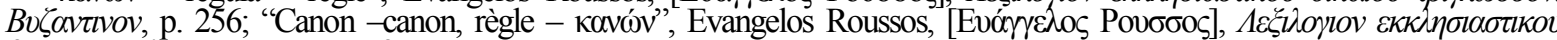

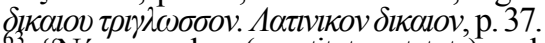

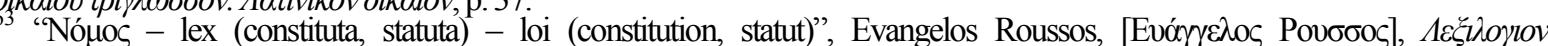

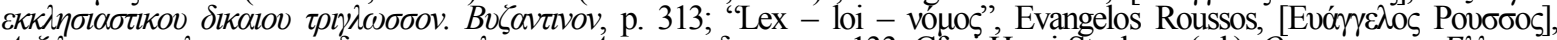

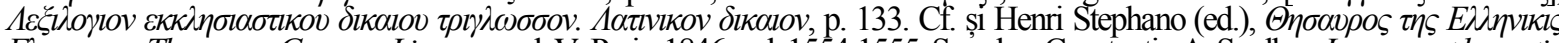

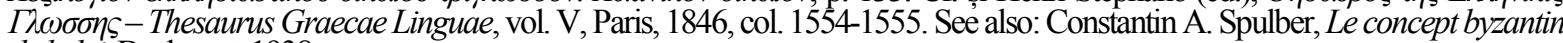
de la loi, Bucharest, 1938.

The Novellae are laws promulgated by the Byzantine emperors, starting with Justinian. This technical term emerged in the $6^{\text {th }}$ century, and was used to define the 158 new imperial constitutions, promulgated after $534 \mathrm{AD}$, when was published Corpus Iuris Iustiniani, until the death of Justinian (565 AD); they were included in a collection named «NovellaeNeopoil». Thus, the Novels (novellae) are constitutions issued by Justinian or his successors, mainly Justin II and Tiberius II, published partly in Latin, partly in Greek, and are laws added to Corpus Iuris Iustiniani. Cf. Emilio Albertario, Introduzione storica allo studio del diritto romano giustinianeo, Milan, 1935, p. 35. See also: Nicolaas Van Der Wal, Manuale Novellarum Justiniani. Aperçu systématique du contenu des Nouvelles de Justinien, Groningen-Amsterdam, 1964; Giuliana Lanata, Legislazione e natura nelle Novelle giustinianee, Naples, 1984; „Du vocabulaire de la loi dans les Nouvelles de Justinien", in Subseciva Groningana 3 (1989), pp. 37-48.

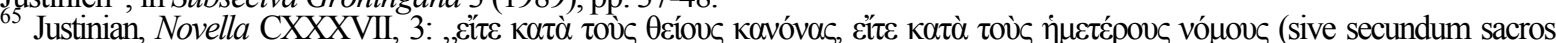
canones sive secundum leges nostras reum invenerit)"; Justinian, Novella CXXIII, 2: „Katà toùs vópovs ì toùs kavóvas (secundum leges aut canones)".

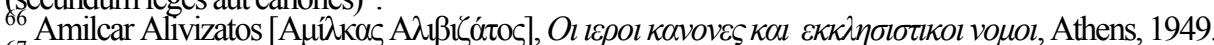

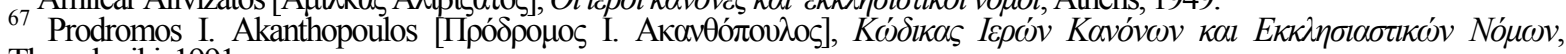
Thessaloniki, 1991.

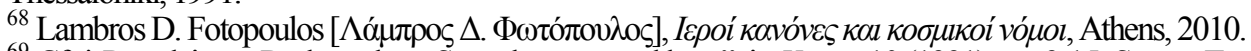

${ }^{69}$ Cf. † Panteleimon Rodopoulos, ,Sacred canons and laws”, in Kanon 10 (1991), pp. 9-15; Spyros Troianos, ,Nomos und kanon in Byzanz", in Kanon 10 (1991), pp. 37-51; Ruth Macrides, ,Nomos and Kanon on paper and in court', in Rosemary Morris (ed.), Church and People in Byzantium, Birmingham, 1990, pp. 61- 85; Andreas Schminck, „Leges ou nomoi ?”, in Spyridon FlogaitisAntoine Pantelis, The Eastern Roman Empire and the Birth of the Idea of State in Europe, London, 2005, pp. 309-316; Bernard H. Stolte, „Of Nomoi and Kanones”, in Subseciva Groningana 6 (1999), pp. 121-136; Evanghélos Karabélias, „Le droit

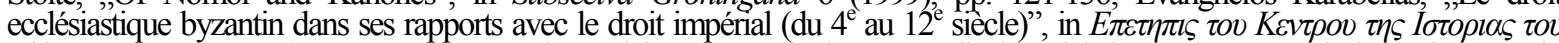

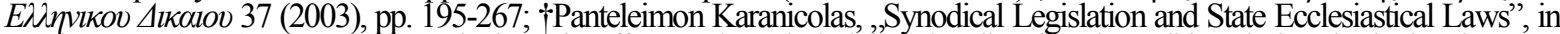

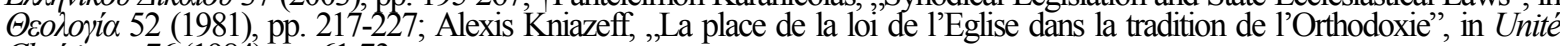
Chrétienne 76 (1984), pp. 61-73.

Spyros Troianos, Le fonti del diritto bizantino, Torino, 2015, pp. 3-5.
} 
created a new relationship between the Church's canons and the Empire's laws, no longer observing the New-Testament symmetry, but imposing an equivalence between ecclesiastical rules and juridical norms. This legislative vision entailed a new stance of the political authority towards the Church: the emperor took the liberty of issuing laws even concerning certain internal aspects of Church life, through his Novels ${ }^{71}$.

The Christian Church, however, in keeping with the teaching of our Saviour Jesus Christ: "Render unto Caesar the things that are Caesar's, and unto God the things that are God's" (Matthew 22, 21), has clearly asserted, ever since her beginnings, that between the Church and the political authority there must be a relationship of distinct cooperation in the spirit of mutual respect ${ }^{72}$. In practice, this relationship is predicated on one of the fundamental canonical principles in the organization and operation of the Church: the principle of autonomy, by which the Church clearly states that in matters of ecclesiastical activities, it is completely independent from any other authority and therefore, it can adopt its own rules (canons).

This type of relationship is based on the canonical doctrine on the nature of Church power, and the relationship between the Church and the state (political) power. In the Law theory, the term power (potestas $-\varepsilon \xi$ ovoí $\alpha$ ) indicates a means or a set of means by which a particular work is conducted, in order to pursue the goals of a politically organized society; the moral expression of power is the authority (auctoritas). Within the social community, politically organized as a state, power is identified by the phrase ,state power” or ,political power” which indicates all the moral (ethical) means as well as the material means necessary to obtain and maintain social order and social progress. In the community of the faithful constituting Christ's Church, power is identified by the phrase „Church power" which indicates all religious, moral and material means employed by the Church in carrying out its salvific work ${ }^{73}$. The main distinction between the two powers - the state's and the Church's - lies in their distinct goals: state power aims to obtain and maintain social order, in order to ensure the progress of society organized as a state, whereas Church power mainly aims to obtain salvation for the faithful people. The essential characteristic of Church power lies in the fact that the main means it resorts to have a religious nature; they are merely underscored by the moral means, and aided by the material means. The religious means, or the elements of Church power are derived from the very work of Lord Jesus Christ, while the moral and material means or elements are provided by the will and activity of the Church members ${ }^{74}$. Therefore, canons are not and cannot be equivalent to a state's laws, regardless of the state's attitude towards the Church and God, since they are pastoral rules of the Church, intended to lead the Christians towards communion with Saviour Jesus Christ.

\section{b. Canons vs laws in the Byzantine Empire}

Even though today this state of affairs is an obvious one and taken for granted, in the past there have been many situations where the political authorities interfered more or less openly in the management of Church affairs. The most frequently quoted case in point is, of course, Byzantium ${ }^{75}$ -

\footnotetext{
${ }^{71}$ For details, see: Konstantinos Pitsakis, „Les novelles dans le droit canonique oriental”, in Luca Loschiavo-Giovanna ManciniCristina Vano (ed.), Novellae Constitutiones: l'ultima legislazione di Giustiniano tra Oriente e Occidente da Triboniano a Savigny: atti del convegno internazionale, Teramo, 30-31 ottobre 2009, Naples, 2011, pp. 91-109.

2 Cf. Alexis Kniazeff, „Le Royaume de César et le Règne de Dieu”, in Contacts 39 (1987), pp. 265-278, 40 (1988), pp. 19-36; Pier Cesare Bori, „Date a Cesare quel che è di Cesare (Mt. 22,21). Linee di storia dell'interpretazione antica”, in Cristianesimo nella storia 7 (1986), pp. 451-464; Liviu Stan, ,Relațile dintre Biserică și Stat’, in Ortodoxia 4 (1952), pp. 353-461.

${ }^{3}$ For a thorough analysis of the concept of Church power during the first Christian millennium, see: Roberto Interlandi, Potestà sacramentale e potestà di governo nel primo millennio. Esercizio di esse e loro distinzione, Rome, 2016, pp. 15-485.

${ }^{74}$ Cf. Ioan N. Floca, Drept canonic ortodox. Legislatie si administrație bisericească, vol. II, Bucharest, 1990, pp. 206-213. Liviu Stan, ,Jus ecclesiasticum. Dreptul în viata Bisericii”, in Studii Teologice 12 (1960), no. 7-8, pp. 467-483; ,Biserica si Dreptul”, in Mitropolia Olteniei 8 (1956), no. 8-9, pp. 482-489. See also: Elio Dovere, ,Auctoritas episcopale e pubbliche funzioni (secc. IVVI)", in Studi sull'Oriente Cristiano 5 (2001), no. 1, pp. 25-41.

Cf. Deno John Geanakoplos, „Church and State in the Byzantine Empire. A Reconsideration of the Problem of Caesaropapism”, in Church History 34 (1965), pp. 381-403; Évelyne Patlagean, „,Théologie politique de Byzance. L'empereur, le Christ, le patriarche", in G. Filoramo (ed.), Teologie politiche. Modelli a confronto, Brescia, 2005, pp. 149-161. See also:
} 
where the political authority closely collaborated with the Church authority, according to a system known as symphony ${ }^{76}$ or synallelia ${ }^{77}$. Actually, the emperor's position within the hierarchy of the Church, a position which according to some authors was accounted for by the sacerdotal character of the basileus $(\beta \alpha \sigma i \lambda \varepsilon v \varsigma)^{78}$, lay at the core of this relationship so extensively and intensely debated ${ }^{79}$. Therefore, the issue of the Church-State relationship boils down to the relationship between the emperor and the Church authority.

Of course, the emperor enjoyed some authority with regard to the churchly matters, but this was a rather limited one. The information provided by Psedo-Codinos is relevant in this sense: in one

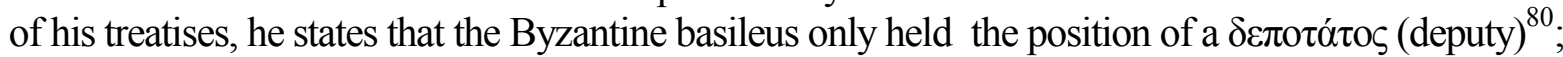
the information on the same office of the basileus is corroborated by Symeon of Thessaloniki, in the 15th century ${ }^{81}$. In the Byzantine Empire, a deputy was in charge of maintaining order in the church and during church processions ${ }^{82}$. Thus, in the Church the emperor was placed among the laypersons ${ }^{83}$, and any office he might have held in the Church was far from the sacerdotal service.

One objection may be raised here: there were cases where some clergymen effectively had a subordinate position to the basileus. Unfortunately this relationship, which sums up the entire matter of the rapport between the Church and the political authority, both in Byzantium and in all countries with an Orthodox majority, has almost always been approached only from the juridical-political angle, that is, from the State authority's standpoint; therefore the priority is granted to the basileus, who is within his own realm of authority there. And, even though this realm is a Christian one, and its political doctrine is theocratic, obviously it is not identical with the Church of Christ. The Church and the Empire are two distinct institutions, although they have common members. Clearly, there are interferences and interconnections between the two institutions, but just as clearly, they can never overlap completely.

In its own realm, the Church has its own hierarchy, where basileus holds no place since „church hierarchy is a world in its own right, always distinct from the State's structure, and its ranks and offices cannot coincide with those of state officials" ${ }^{\prime 4}$. Of course, one might again point out that, in the Byzantine Empire, the basileus participated in the election of the patriarch ${ }^{85}$, while in his turn, the patriarch was the central figure during the emperor's crowning ceremony ${ }^{86}$.

Moreover, even though the imperial authority did intervene in dogmatic debates - this was a characteristic aspect of Justinian's policy -, we mention that the emperor (basileus) never had the

Konstantinos Pitsakis, „Quelques réflexions au sujet d'individu et pouvoir dans l'Empire romain d'orient: idéologie politique et pensée canonique", in Méditeranées 16(1998), pp. 138-166.

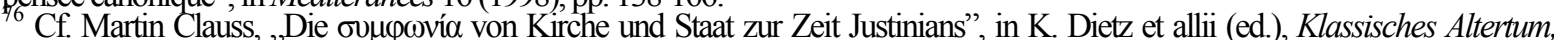
Spätantike und frühes Christentum: Adolf Lippold zum 65 Geburtstag gewidmet, Würzburg, pp. 579-593.

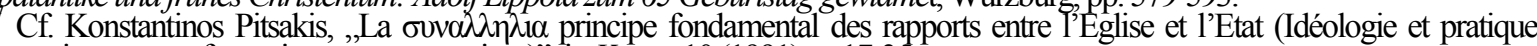
byzantines et transformations contemporaines)", in Kanon 10 (1991), p. 17-35.

See : Konstantinos Pitsakis, „Sainteté et empire. A propos de la sainteté impériale: formes de sainteté «d'office» et de sainteté collective dans l'Empire d'Orient?', in Bizantinistica III (2001), p. 155-227.

79 Konstantinos Pitsakis, „Empire et Eglise le modèle de la Nouvelle Rome: la question des ordres juridiques”, in Maria Pia Baccari, (ed.), Diritto e religione. Da Roma a Costantinopoli a Mosca. Rendiconti del XI Seminario «Da Roma alla terza Roma». Campidoglio, 21 aprile 1991, Rome, 1991, p. 105.

${ }_{80}$ Jean Verpeaux, Pseudo-Kodinos. Traité des offices, Paris, 1966, p. 264.

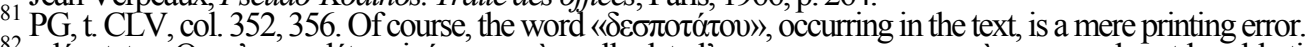

82 „dépotatos. On n'a pas déterminé encore à quelle date l'empereur commence à se parer de cet humble titre”, Jean Darrouzes, Recherches sur les offikia de l'Eglise byzantine, Paris, 1970, p. 215.

${ }_{83}$ Konstantinos Pitsakis, ,L'empereur romain d'Orient: un laïc”, in Kanon 15 (1999), pp. 196-221.

84 'La hiérarchie de l'Eglise est considérée comme un monde à part, toujours distinct des corps d'Etat; ses rangs ne se confondent pas avec ceux des dignitaires auliques dans les cortèges et les receptions", Jean Darrouzes, Recherches sur les offikia de l'Eglise byzantine, Paris, 1970, p. 28.

Cf. Leszka B. Malgorzata, "The Attitude of Early Byzantine Emperors towards the Process of Electing Bishops of Constantinople", in Mélanges d' histoire byzantine offerts à Oktawiusz Jurewicz à l'occasion de son soixante-dixième anniversaire, Lódź, 1998, pp. 110-127.

${ }^{86}$ Cf. Panayotis A. Yannopoulos, „Le couronnement de l'empereur à Byzance: rituel et fond institutionnel”, in Byzantion 61 (1991), pp. 71-91. 
right to vote within a synod; this right belonged exclusively to the bishops ${ }^{87}$. We note the fact that despite the privileges held by the basileus, the Church never accepted any laws that might have contradicted its canons, not even during the Christological controversies of the $5^{\text {th }}$ century, or under the iconoclast emperors of the 8th century, or during the attempts at union with Rome, during the $13^{\text {th }}-15^{\text {th }}$ centuries.

Admittedly, in the Byzantine Empire the Church and political authority worked closely together. In the imperial milieu, this unity was manifest through the presence of Byzantine prelates in the ranks of the State official hierarchy. In the ecclesiastical milieu, the Church and the political authority were also cooperating, but political authorities were present only in a lay capacity. The subordination of clergy to lay authority was only relative, as it existed only within the imperial milieu. In the ecclesiastical milieu, however, things were different. Actually, the Byzantine stance on the human society created two hierarchical systems: that of the Church, and that of the Empire. Both were Christian, even if the latter represented the „,rule of the Caesar", both were theocratic ${ }^{88}$, for they confessed and acknowledged a single authority - Saviour Jesus Christ; moreover, both coexisted in the same shared space, and pursued the same final goal - the union of the visible world with The Most High. However, the two hierarchical systems were completely distinct and different, and every attempt at merging them proved to be a failure. A relevant illustration of the relationship between the two hierarchical systems was provided by the Epanagoga / Eisagoga ${ }^{89}$ (a code of Byzantine law, issued between 879 and $886 \mathrm{AD}$ ), where legislators' intention was to juxtapose the two systems, not combine or merge them. Another example demonstrating this view is provided by the episcopal lists dating from the $9^{\text {th }}-10^{\text {th }}$ centuries. These joint lists of prelates and state officials ceased to exist afterwards.

As regards the court trials, already under Emperor Constantine the Great, the existence of Church's own trial courts influenced the administration - not only of civil justice, but also of criminal justice, by consecrating privileged institutions that favoured either the Church in general (by acknowledging the Church trial courts) ${ }^{90}$, or the clergymen summoned to the Court for trials in private matters, who presented themselves only before the Church authorities (privilegium fori) ${ }^{91}$.

We also note the influence of Roman law on canon theology, especially after the $4^{\text {th }}$ century when the Church acquired an official standing in the Roman Empire. A substantial part of the terminology describing the institutions and mechanisms by which the Church operates, comes from the Roman law. It was absolutely natural for the Church to tap into the (highly developed) juridical culture of the times. However, it is an undisputed fact that the substance and specific character of canon theology are not borrowed from the Roman law, but are grounded in the Apostolic tradition and the initiatives inspired by the Holy Spirit in carrying out the pastoral mission of the Church, at any point in the history. Consequently, its great importance notwithstanding, the contribution of

\footnotetext{
87 "There is no trace in the acts of the council of Constantine voting with the bishops. He only confirmed their decision and made it legal”, Johannes A. Straub, „Constantin as Kotvos Eлıбколоб: Tradition and Innovation in the Representation of the First Christian Emperor's Majesty”, in Dumbarton Oaks Paper 21 (1967), p. 49. See also: Francis Dvornik, „Emperors, Popes and General Councils", in Dumbarton Oaks Paper 6 (1951), p. 9.

88 "La doctrine théocratique domine l'histoire de Byzance et l'explique; toutefois, loin d'apporter au pouvoir impérial force et stabilité, elle est pour lui une cause de faiblesse. L'empereur choisi par Dieu ne règne, en effet, que par la protection divine. Si Dieu cesse de le soutenir et de l'inspirer, son mandat est périme; l'empereur exerce le pouvoir sans droit et il n'est plus qu'un intrus sur le trône. La moindre secousse peut le renverser. Dieu, qui donne le pouvoir, n'en garantit, en effet, la durée que dans la mesure où le pouvoir est exercé selon ses vues, qui sont, d'ailleurs impénétrables. Dans le cas contraire, Dieu peut, selon l'énergique expression de la Bible, se repentir et porter son choix sur un candidat plus digne. Il convient donc de scruter à tout moment l'opinion divine pour savoir si elle n'a pas changé.”, Rodolphe Guilland, „Le droit divine à Byzance”, in Seorsum impressum ex commentariis Societatis Philologae Polonorum XLII (1947), p. 143.

${ }^{89}$ Cf. Epanagoge legis Basilii Leonis et Alexandri, in Zachariae Von Linghental, Jus Graecoromanum, vol. 2, Athens, 1931, pp. 229-368

${ }_{91}$ Cf. Giulio Vismara, La giurisdizione civile dei vescovi (secoli I-IX), Milan, 1995.

91 Cf. Antonio Banfi. "Habeant illi iudices suos". Studi sull'esclusività della giurisdizione ecclesiastica e sulle origini del "privilegium fori" in diritto romano e bizantino, Milan, 2005. See also: Helen Saradi, ,The Byzantine Tribunals: Problems in the Application of Justice and State Policy $\left(9^{\mathrm{t}}-12^{\mathrm{t}} \text { c. }\right)^{\text {"', }}$ in Revue des études byzantines 53 (1995), pp. 165-204.
} 
Roman law to the development of canon theology, especially in the Christian East, is confined to the technical-instrumental aspects, having no doctrinal relevance since canon theology is exclusively rooted in the Christian teachings of the faith ${ }^{92}$.

\section{c. Church canons vs State laws: today's situation}

Starting from the $6^{\text {th }}$ century onwards, the State laws addressing the organization and operation of the Church were repeatedly published alongside the texts of the Holy Canons, thus creating the false impression that the two categories of regulations were equivalent. Moreover, emperor Justinian's Novela 131, declared the canons issued by the first four Ecumenical Councils to have equal authority to the law. Hence the erroneous perception that the Church possesses its own law system (ius/dikolov), identified by Western theologians as „canon law” (ius canonicum) - a phrase subsequently adopted by some Orthodox authors. We note that in Western Europe, Rudolph Sohm (1841-1917) - a Lutheran jurist and an expert in the history of the law, examined the evolution of the influence of Roman law on the Church; he reached the conclusion that since the $12^{\text {th }}$ century, especially by the issuing of Decretum Gratiani ${ }^{33}$, in the Western Church this influence was manifest in the emergence of a legal formalism which resulted in the idea that the state was governed by the Church canons - that is, by canon law or Church law ${ }^{94}$. Of course, all Roman-Catholic theologians criticized such perception and offered explanations for the statement of the German jurist, generally acknowledging the significant influence of Roman law on Catholic theology but refusing to accept Sohm's conclusions ${ }^{95}$. The result of this controversy was a re-positioning of Catholic theology, which especially in the aftermath of the Second Vatican Council (1962-1965), began to refer more and more insistently to a ,theology of canon law/ canon law theology" ${ }^{96}$ (sic!).

Most Orthodox theologians, however, reject the postulate of an equivalence between State laws and Church canons, emphasizing the difference in nature and competencies between these two sets of regulations. The law is thus an imperative norm, issued by a holder of authority over a social group organized on a territory, and sanctioned by the collective force of the respective group. The canon, on the other hand, is a pastoral rule issued by the Church authority and impacting the ecclesial milieus, having an exclusively spiritual-thaumaturgic character. From the standpoint of their applicability, the law provisions are limited in time and confined to a particular territory, whereas the principles contained by the holy canons are universally valid and relevant for all Christians at all times.

There are, however, some Orthodox theologians who continue ungroundedly regard „,canon law" as a subset or component part of law (ius) in general. However, reputed scholars have

\footnotetext{
${ }^{92}$ Cf. Konstantinos Pitsakis, ,Droit romain et droit canonique oriental', in Cristianità d'Occidente e cristianità d'Oriente (secoli VI-XI): 24-30 aprile 2003, Spoleto, 2004, vol. 2, pp. 1435-1469; ,Ius Graeco'Romanum et normes canoniques dans les Eglises de tradition orthodoxe”, in Raffaele Coppola (ed.), Atti del Congresso Internazionale „Incontro fra canoni d'Oriente e d'Occidente, vol. 1, Bari, 1994, pp. 99-132. See also: Elio Dovere, „Diritto romano e prassi conciliare ecclesiastica (secc. III-IV)”, in I concili della cristianità occidentale: secoli III-IV. XXX incontro di studiosi dell'Antichità cristiana, Roma 3-5 maggio 2001, Rome, 2002, pp. 7-24.

Decretum Gratiani is a collection of papal canons and decrees, officially titled Concordia discordantium canonum, and compiled by the Camaldolese monk Gratianus in early $12^{\text {th }}$ century (1140-1142). For details, see: Anders Winroth, The Making of Gratian's Decretum, Cambridge, 2000.

${ }_{95}$ Cf. Rudolph Sohm, Das altkatholische Kirchenrecht und das Dekret Gratians, Munich, 1918, pp. 536-674.

${ }^{95}$ Cf. Yves-Marie Congar, ,Rudolf Sohm nous interroge encore”, in Revue des sciences philosophiques et théologiques 57 (1973) pp. 263-294; Roberto Righi, , Rudolph Sohm e il diritto canonico”, in Carlo Fantappiè (ed.), Itinerari culturali del diritto canonico nel Novocento, Torino, 2003, pp. 33-71; Klaus Mörsdorf, ,Altkanonisches «Sakramentsrecht». Eine Auseinandersetzung mit den Anschauungen Rudolph Sohm über die inneren Grundlagen des Decretum Gratiani”, in Studia Gratiani 1 (1953), pp. 483-503.

${ }^{6}$ For further details, see: Eugenio Corecco, „Teologia del diritto canonico”, in Giuseppe Barbaglio - Severino Dianich (ed.), in Nuovo Dizionario di Teologia, Rome, 1977, pp. 1711-1753; Gianfranco Ghirlanda, Introduzione al diritto ecclesiale. Lineamenti per una teologia del diritto nella Chiesa, Rome, 2013. It is noteworthy that some orthodox authors speak about a ,theology of orthodox canon law". Cf. Patrick Viscuso, „A Late Byzantine Theology of Canon Law”, in The Greek Orthodox Theology Review 34 (1989), pp. 203-219; Irimie Marga, „Theology of Orthodox Canon Law”, in Casian Ruset (ed.), Simpozion international ,, Statutul actual pentru organizarea și funcționarea Bisericii Ortodoxe Române”.: Carasenbeș, 2015, Cluj-NapocaCaransebes, 2016, pp. 128-143.
} 
demonstrated that from the earliest times, there has been a distinction between Church canons and State laws and that ,there was no «canon law» in Byzantium" "97.

Some authors, in order to emphasize the distinction between canons and laws, stress the exclusively pastoral value of the Holy Canons and their character which is thaumaturgical par excellence, also pointing out the risk entailed by this confusion: that the Church might create a juridical system, parallel to that existing in the state where the respective Church is established and operates. The American professor Lewis J. Patsavos, of Holy Cross University, Boston, states:

although generally referred to as canon law, such a name given to the Church's law suggests a parallel to secular law. It would be more correct to call it the tradition of the holy canons, since they are the object of its concern ${ }^{98}$.

Actually, canons hold no legal status in the states where the Church is established and operates; they (the canons) are pastoral rules prescribed to Christians by the church authority and received by consensus of the entire Church, in order to help its members to maintain, intensify or regain communion with Saviour Jesus Christ. On the other hand, we must also note that the laws passed by the state authorities in order to regulate the regime of religious freedom, as well as the state's manner of relating to the religious communities within it, including the Church, have always constituted a distinct body inside civil law, a body usually identified as church/ecclesiastical law (ius ecclesiasticum) or public ecclesiastical law (ius ecclesiasticum publicum). Recently, the French professor Francis Messner, of the University of Strasbourg, pointing out that currently in the West there are also non-Christian religious communities that are juridically acknowledged by the states where they are established and operate, suggested that the law addressing them should no longer be termed church/ecclesiastical law, but ,law of religions"

Based on the above considerations, we deem that all aspects pertaining to the knowledge, observance and application of the Holy Canons in the life of the Church, can be exhaustively identified and designated by the phrase „canon theology”, and that all state regulations addressing the juridical regime of the Church, in particular, can be defined by the phrase „ecclesiastical/church law", while the general legal framework encompassing the juridical regime of religious freedom and religious communities, can be termed ,law of religions" or ,religious law”. In this sense, we note that although canon theology continues to be often assimilated to, or even equated with, the science of law (some authors even deem it to be part of law in general), it does not employ the juridical terminology and concepts. For instance, canon theology does not know the acts of abrogation (complete abolishing or invalidation), derogation (temporary, partial abolishment) or prorogation (extending the validity of a law issued for a particular period) ${ }^{100}$. Also, canon theology does not include a criminal section, as the law does with the criminal law branch, since the holy canons do not stipulate or prescribe any punishments (poenae) for the trespassers, but only epithemia or penance, exclusively aimed at spiritual healing.

\section{THE RELATIONSHIP BETWEEN CHURCH CANONS AND DOGMAS}

Although originally no clear terminology was in place, in order to designate the different types of conciliar decisions, the Church subsequently consecrated specific terms to distinguish doctrinal from disciplinary decrees. This created a clear distinction between dogmatic decisions

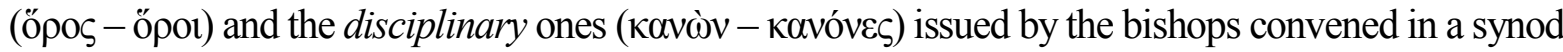

\footnotetext{
${ }^{97}$ David Wagshal, Law and Legality in the Greek East: The Byzantine Canonical Tradition, 381-883, p. 152. See also: Danilo Ceccarelli Morolli, Il diritto dell'Impero romano d'Oriente, Rome, 2016, pp. 137-166.

98 Lewis J. Patsavos, Valentele duhovnicești ale Sfintelor Canoane, Sibiu, 2012, p. 21.

99 Francis Messner, „Du droit ecclésiastique au droit des religions: évolution d'une terminologie”, in Revue de Droit Canonique, 47 (1997), no. 1, pp. 143-160. See also: Francis Messner, Dictionnaire droit des religions, Paris, 2015.

Constantin Rus, Drept bisericesc, Arad, 2000, p. 46.
} 
or council, and then received and acknowledged by the Church ${ }^{101}$. According to the Orthodox theologians, the first difference between these two types of Council decisions is that, irrespective of the evolution of the pastoral needs of the Church, the dogmatic decisions (dogmas) can never be altered $^{102}$, while the disciplinary decisions (canons), if the pastoral necessity arises, can be completed, amended, modified or clarified only by an ecumenical council ${ }^{103}$ - the supreme authority in the Orthodox Church ${ }^{104}$, when such council can convene, or otherwise by consensus Ecclesiae dispersae, if an ecumenical council cannot convene.

A remark is in order here: too often some theologians tend to regard the synod in an excessively formal way, more precisely they consider only its organizational side - a different, even opposite perception from that of the Bishop of Rome in the Roman-Catholic Church. To some Orthodox theologians, the synod is not only the Church body exerting the supreme authority but, according to their view, the synod also enjoys an infallibility of sorts. It is then necessary to point out that, according to the canonical tradition and doctrine, the synods as assemblies of bishops represent the supreme authority in the autocephalous Churches and that the ecumenical council is the supreme authority in the Orthodox Church; however, the ecumenical council is never placed above the autocephalous Churches, because any conciliar decision, even the decisions issued by an ecumenical council, takes effect only if it is accepted by the entire Church, that is, by each autocephalous Orthodox Church.

We must also note the fact that a doctrinal or disciplinary decision passed by a synod of bishops, including an ecumenical council, is not immediately applicable in the Church, but it becomes officially valid and takes effect in the life of the Church only after it has been accepted by the entire Church, because according to the Orthodox theology, infallibility does not belong to an ecumenical council but to the entire Church since, the Church as a whole is the body of Christ and as such it is infallible as Christ is infallible" 105.

The second distinction between the two types of conciliar decisions accepted by the entire Church, lies in the fact that the dogmas define what Christians believe and confess (the teachings of the faith) ${ }^{106}$, while canons indicate the practical ways in which Christians experience and confess the teachings of the faith through their very lifestyle. These two types of conciliar decisions constitute the fundamental structure of the Church.

\section{CONCLUSIONS}

All the above demonstrate that from its very beginnings, the Church has postulated (based on the words of Saviour Jesus Christ - Matthew 22, 21) a distinction in both nature and purpose between itself and any form of state organization; consequently, it has coined a new

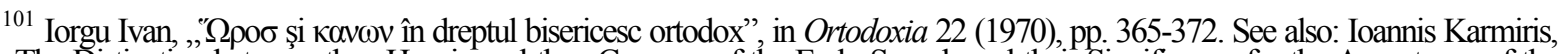
„The Distinction between the «Horoi» and the «Canons» of the Early Synods and their Significance for the Acceptance of the "Council of Chalcedon by the Non-Chalcedonian Churches", in Greek Orthodox Theological Review 16 (1971), pp. 79-107; Nicolae Chitescu, „Deosebirea dintre Oros și Canon și importanţa ei pentru receptarea Sinodului de la Calcedon”, in Ortodoxia 22 (1970), pp. 347-364.

${ }_{103}$ Cf. can. 1 second Ecumenical Council; can. 7 Third Ecumenical Council.

103 "The Ecumenical Councils make two types of decisions: 1. Doctrinal, or theological, which are infallible, unchangeable, and must be believed by every Orthodox. 2. Disciplinary or administrative canons. The disciplinary canons cover various questions as to the performance of sacraments, jurisdiction of parishes, dioceses, marriage and divorce questions, penance and others. These canons are changeable by other Ecumenical Council, and they are not infallible. They are binding upon the faithful, however, and are to be enforced by the clergy", George H. Demetrakopoulos, Dictionary of Orthodox Theology: A Summary of the Beliefs, Practices and History of the Eastern Orthodox Church, New York, 1964, p. 39.

4 "Selon l'ecclésiologie orthodoxe seule l'Eglise est le royaume de Dieu sur la terre et l'organe de Dieu pour le salut des hommes, et les conciles œcuméniques sont ses organes d'autorité suprême", Nicolae Dură, Le régime de la synodalité selon la législation canonique conciliaire, oecuménique du Ir millénaire, Bucharest, 1999, p. 304; Cf. also: Serge Verkhovskoy, „The Highest Authority in the Church”, in Saint Vladimir's Theological Quarterly 4 (1960), pp. 76-88; $\uparrow$ Pierre L'Huillier, „Le concile gecuménique comme autorité suprême dans l'Eglise", in Kanon 2 (1974), pp. 128-142.

105 Dumitru Stăniloae, Teologia Dogmatică Ortodoxă, vol. 2, Bucharest, 1997, p. 118. See also: Bernard Sesboüé, Histoire et théologie de l'infaillibilité de l'Eglise, Bruxelles, 2013.

For a presentation of the concept of dogma in the Orthodox Church, see: Dumitru Stăniloae, „Noțiunea dogmei”, in Studii Teologice 16(1964), no. 9-10, pp. 533-571.
} 
term: canon ( $\kappa \alpha v \omega ́ v)$, by which it defined its own pastoral rules leading to communion with Lord Jesus Christ.

Etymologically, the term canon designates a rule, prescription, norm, guideline, model,

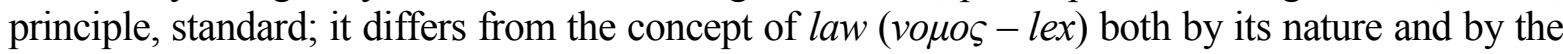
authority issuing it, as well as its purpose. In a State, the law is a mandatory norm, issued and defended by the state authority, describing or regulating specific relationships between persons and organizations, and prescribing the punitive measures against the trespassers. In contrast, within the Church the canon is a pastoral rule given to the Christians by the ecclesiastical authority, in order to assist them in their free (voluntary) decision to maintain, to boost or to regain communion with Christ our Saviour; such rule has already been received by the consensus of the entire Church. Thus in the theological idiom, the term canon has been used ever since the apostolic times, originally to designate a ,guideline" for Christian life, including all the evangelical and apostolic prescriptions. Subsequently, from the $4^{\text {th }}$ century onwards, the term canon became established as a denominator for the disciplinary decisions passed by ecumenical councils, to distinguish them from the dogmatic decrees of the councils and to indicate the pastoral rules of the Church, in contrast with the State laws. Also, the ecclesiastic language employs the term canon to identify particular ecclesial realities, structured according to precise rules. Thus since the first Christian centuries, the list of Bible books accepted by the Church has been known as the „biblical canon”, and the catalogue of saints has been known as "saints' canon”. Also, the phrase „Eucharistic canon” designates the main part of the Holy Liturgy - the liturgical anaphora. From the $7^{\text {th }}$ century onwards, a particular type of poetic hymn made up of nine odes has been termed canon.

However, in today's theological language, the most widely used connotation of the term canon is that of a pastoral rule, passed by a council and received by the entire Church. The term is usually employed in the plural form, in the phrase ,holy canons" or ,holy and divine canons" to define the set of pastoral rules applied in the Church. In conclusion, the holy canons are pastoral rules sanctioned by the Church authority, and indicating how the Church members ought to act and behave under concrete circumstances, so that their actions may receive a positive assessment in relation to religious faith; ultimately, they aim at bringing man in communion with Lord Jesus Christ. The fundamental principles contained in the holy canons are valid at all times, for all those who confess Christ and want to reach full communion with Him.

In its interaction with the state authority, the Church has resorted to State legislation in order to make it into an auxiliary to its salvific work. The synthesis between the State's need to know and issue legal regulations for the ecclesiastic communities established on its territory, on the one hand, and the Church's efforts to built a distinct cooperation with the authorities of the State where it is organized and operates, in the spirit of mutual respect, on the other hand, has produced a specific domain of the Law, including all the state legislation that addresses ecclesial life; this used to be known as ,ius ecclesiasticum" („Church law”). Today, however, some authors consider this to be an outdated phrase (rendered obsolete by the existence of religious non-Christian communities, acknowledged by States) and suggest the alternative phrase „religious law”.

Regarding the relationship between Church canons and dogmas, we note that both are decisions reached by the ecclesiastical authority, sanctioned by councils and consensually accepted by the entire Church. The main distinction between them lies in the contents they define, as well as the manner in which they can or cannot be amended, completed or explained if the pastoral necessity arises. 
Thus we may assert that the holy canons provide the practical solutions for the problems met by the Church at the respective times, solutions provided by pastoral rules consensually throughout the Church; every ecclesiastical regulation (decisions issued by councils/synods or by bishops) in the Church, at any time, must express both the canonical tradition and doctrine, and the pastoral-missionary attitude of the ecclesiastical authority bodies.

\section{BIBLIOGRAPHY:}

[1] Abellan Francisco Sanchez, „Canon Romano”, in Helmántica 25 (1974), pp. 245-319;

[2] Afanassieff Nicolas, „The Canons of the Church: Changeable or Unchangeable?”, in Saint Vladimir's Theological Quarterly 11 (1967), pp. 54-58;

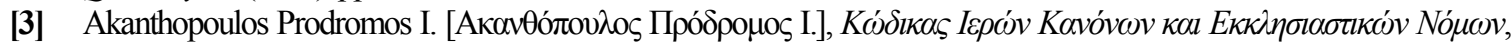
Thessaloniki, 1991;

[4] Albertario Emilio, Introduzione storica allo studio del diritto romano giustinianeo, Milan, 1935;

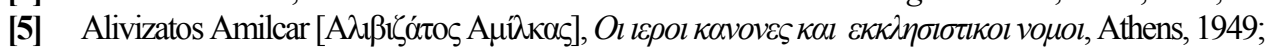

[6] Alivizatos Amilcar, „Les rapports de la législation ecclésiastique de Justinien avec les canons de l'Eglise”, in Atti del Congresso Internazionale di Diritto Romano (Bologna e Roma XVI-XXVII aprile MCMXXXIII), vol. II, Pavia, 1935, pp. 79-87;

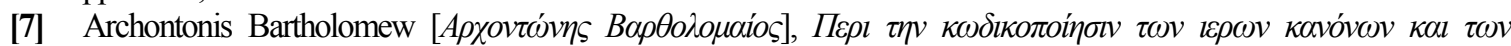

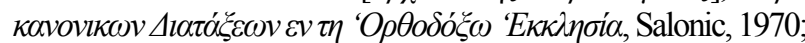

[8] Archontonis Bartholomew, „A Common Code for Orthodox Churches”, in Kanon 1 (1973), pp. 45-53;

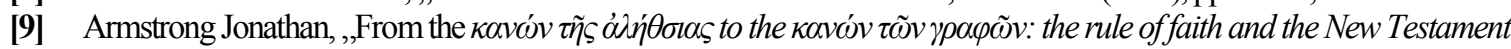
canon", in Ronnie Rombs - Alexander Hwang (ed.), Tradition and the Rule of Faith in the Early Church: Essays in Honor of Joseph T. Lienhand S.J., Washington, 2010, pp. 30-47;

[10] Arocena Solano Félix María, „En torno al canon romano”, in Burgense 36 (1995), no. 2, pp. 393-425; Baraznò Alberto (ed.), Il cristianesimo nelle leggi di Roma imperiale, Milan, 1996;

[11] Banfi Antonio, "Habeant illi iudices suos". Studi sull'esclusività della giurisdizione ecclesiastica e sulle origini del "privilegium fori" in diritto romano e bizantino, Milan, 2005;

[12] Barone Adesi Giorgio, „Libertà religiosa e convivenza delle religioni: nell'editto di Milano e negli indirizzi legislativi costantiniani”, in Ilaria Zuanazzi (ed.), Da Costantino à oggi. La libera convivenza delle religioni. Atti del Seminario interdisciplinare nel $1700^{\circ}$ anniverario dell'Editto di Milano organizzato dai Dottorati di ricerca in "Diritti e Istitutzioni" e in "Diritto, Persona e Mercato" del Dipartimento di Giurisprudenza dell'Università degli Studi di Torino (Torino, 24 ottobre 2013), Naples, 2015, pp. 11-40;

[13] Barone Adesi Giorgio, „Legittimazione e limiti di vigenza dell'ordinamento canonico nell'impero romano”, in Gian Luigi Falchi - Antonio Iaccarino (ed.), Legittimazione e limiti degli ordinamenti giuridici. XIV Colloquio Giuridico Internazionale, Città del Vaticano, 2012, pp. 319-336;

[14] Beekes Robert, Etymological Dictionary of Greek, vol. 1, Leiden, 2010;

[15] Berdnikov Ilya Stepanovich [Бердников Илья Степанович], Основные начала церковного права Православной Церкви, Kazan, 1902;

[16] Berechet Ștefan G., Legătura dintre Dreptul bizantin și românesc, vol. I, part I, Vaslui, 1937;

[17] Boicu Dragoș, „Teodosie cel Mare şi Edictul de la Tesalonic (28 februarie 380). Circumstanţe, comentariu, receptare”, in Revista Teologică 94 (2012), no. 2, pp. 186-207;

[18] Bori Pier Cesare, „Date a Cesare quel che è di Cesare (Mt. 22,21). Linee di storia dell'interpretazione antica”, in Cristianesimo nella storia 7 (1986), pp. 451-464;

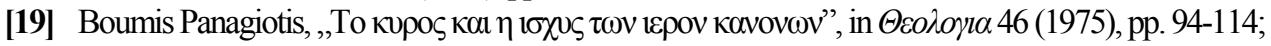

[20] Bovini Giuseppe, La proprietà ecclesiastica e la condizione giuridica della Chiesa in età precostantiniana, Milan, 1949;

[21] Bratsiotis Panagiotis, Die Grundprinzipien und Hauptmerkmale der Orthodoxen Kirche, Athens, 1938;

[22] Brakke David, „Canon Formation and Social Conflict in Fourth-Century Egypt: Athanasius of Alexandria's ThirtyNinth Festal Letter", in The Harvard Theological Review 87 (1994), no. 4, pp. 395-419;

[23] Bruce Frederick Fyvie, The Canon of the Scripture, Downers Grove - Illinois, 1988;

[24] Cagin Paul, L'Eucharistia, canon primitif de la messe ou formulaire essentiel et premier de toutes les liturgies ?, Paris, 1912;

[25] Cardinale Antonio -Verdelli Alessandro, Il cristianesimo da culto proibito a religione dellimpero romano. La nascita del potere della Chiesa nel IV secolo d. C., Roma, 2010;

[26] Ceccarelli Morolli Danilo, Il diritto dell'Impero romano d'Oriente, Rome, 2016; 
[27] Chantraine Pierre, Dictionnaire étymologique de la langue grecque. Histoire de mots, Paris, 1968;

[28] Chițescu Nicolae, „Deosebirea dintre Oros și Canon și importanța ei pentru receptarea Sinodului de la Calcedon”, in Ortodoxia 22 (1970), pp. 347-364;

[29] Cipriani Anastasio, L'Editto di Milano e il suo valore politico-religioso, Rome, 1913;

[30] Clauss Martin, „Die oo $\mu \varphi \omega v i ́ \alpha$ von Kirche und Staat zur Zeit Justinians”, in K. Dietz et allii (ed.), Klassisches Altertum, Spätantike und frühes Christentum: Adolf Lippold zum 65 Geburtstag gewidmet, Würzburg, pp. 579-593;

[31] Coman Petre, ,Problema obiceiului de drept în sfintele canoane”, in Studii Teologice 21 (1969), no. 5-6, pp. 399-409;

[32] Congar Yves-Marie, „Rudolf Sohm nous interroge encore”, in Revue des sciences philosophiques et théologiques 57 (1973), pp. 263-294;

[33] Constantinescu Iulian Mihai L., „Principiile canonice fundamentale și aplicarea formei canonice în organizarea şi conducerea Bisericii', in Mitropolia Olteniei 67 (2015), no. 14, pp. 178-196;

[34] Corecco Eugenio, „Teologia del diritto canonico”, in Giuseppe Barbaglio - Severino Dianich (ed.), in Nuovo Dizionario di Teologia, Rome, 1977, pp. 1711-1753;

[35] Cozma Ioan, „Cuvântul canon în terminologia bisericească. Sensul și folosirea lui în legislația canonică sinodală”, in Altarul Reîntregirii 2 (2004), pp. 232-251;

[36] Darrouzes Jean, Recherches sur les offikia de l'Eglise byzantine, Paris, 1970;

[37] Demetrakopoulos George H., Dictionary of Orthodox Theology: A Summary of the Beliefs, Practices and History of the Eastern Orthodox Church, New York, 1964;

[38] Di Mauro Todini Antonella, Aspetti della legislazione religiosa del IV secolo, Roma, 1990;

[39] Dovere Elio, „Diritto romano e prassi conciliare ecclesiastica (secc. III-IV)”, in I concili della cristianità occidentale: secoli III-IV. XXX incontro di studiosi dell'Antichità cristiana, Roma 3-5 maggio 2001, Rome, 2002, pp. 7-24;

[40] Dovere Elio, ,Auctoritas episcopale e pubbliche funzioni (secc. IV-VI)”, in Studi sull'Oriente Cristiano 5 (2001), no. 1, pp. 25-41;

[41] Dron Constantin, Valoarea actuală a canoanelor Bucharest, 1928 (republished in 2016 at Iași by Emilian Iustinian Roman);

[42] Dură Nicolae, „Dreptul și religia. Normele juridice și normele religios-morale”, in Analele Universității „,Ovidius” 1 (2003), p. 19-31;

[43] Dură Nicolae, ,Edictul de la Milan (313) și impactul lui asupra relațiilor dintre Stat și Biserică. Câteva considerații istorice, juridice și ecleziologice", in Mitropolia Olteniei 64 (2012), no. 5-8, pp. 28-43;

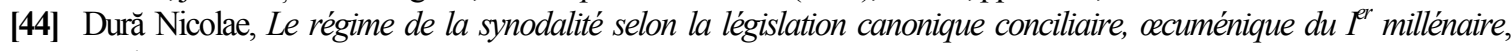
Bucharest, 1999;

[45] Dură Nicolae, ,Principiile canonice, fundamentale, de organizare şi funcţionare a Bisericii Ortodoxe şi reflectarea lor în legislația Bisericii Ortodoxe Române", in Mărturie Ortodoxă 6 (1987), pp. 127-144 [republished in Revista de Teologie Sfântul Apostol Andrei 5 (2001), pp. 129-140];

[46] Dvornik Francis, ,Emperors, Popes and General Councils”, in Dumbarton Oaks Paper 6(1951), pp. 1-23;

[47] Erdö Peter, Storia delle fonti del diritto canonico, Venice, 2008;

[48] Erdö Peter, „Quid significat, ,ex” in iure canonico antiquitatis (saecula III-IV)", in Periodica 76 (1987), pp. 381-412;

[49] Erickson John, „The Orthodox Canonical Tradition”, in Saint Vladimir's Theological Quarterly 27 (1983), pp. 155167

[50] Falchi Gian Luigi, ,Legislazione e politica ecclesiastica nell'Impero romano dal 380 d.C. al Codice Teodosiano", in Atti della Accademia Pontaniana VI (1986), pp. 179-212;

[51] Ferme Brian Edwin, Introduction to the History of the Sources of Canon Law. The Ancient Law up to the Decretum of Gratian, Montreal, 2007;

[52] Floca Ioan N., Drept canonic ortodox. Legislație și administrație bisericească, vol. I-II, Bucharest, 1990;

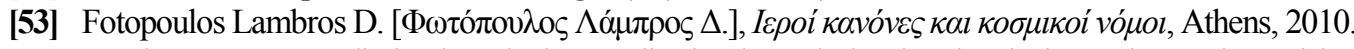

[54] Gaudemet Jean, „L'Edit de Théssalonique: police locale ou déclaration de principe ?’, in Henri W. Pleket - Arthur M. F. Verhoogt (ed.), Aspects of the Fourth Century A.D. Proceedings of the Symposium „Power and Possession. State, Society and Church in the Fourth Century A.D. ", Leiden, 3-5 June 1993, Leiden, 1997, pp. 43-51;

[55] Gaudemet Jean, „Politique ecclésiastique et législation religieuse après l'Edit de Théodose I de 380”, in Atti dell'Accademia Romanistica Costantiniana 7 (1986), pp. 1-22;

[56] Gaudemet Jean, „Elementi giuridici romani nella formazione del diritto ecclesiastico dei primi secoli”, in Mondo classico e cristianesimo. Atti del convegno su Mondo greco-romano e cristianesimo, Roma 13-14 maggio 1980, Rome, 1982, pp. 171-182;

[57] Geanakoplos Deno John, „Church and State in the Byzantine Empire. A Reconsideration of the Problem of Caesaropapism", in Church History 34 (1965), pp. 381-403;

[58] Getcha Job, ,La canonisation des saints dans l'Eglise orthodoxe”, in Esprit et vie 115 (2004), pp. 34-38; 
[59] Ghirlanda Gianfranco, Introduzione al diritto ecclesiale. Lineamenti per una teologia del diritto nella Chiesa, Rome, 2013

[60] Gholam Samir, „Obiceiul ca izvor în dreptul romano-bizantin și în tradiția patristico-canonică a Bisericii Ortodoxe”, in Studii Teologice 27 (1975), no. 5-6, pp. 452-463;

[61] Grigoriță Georgică, Sfintele și dumnezeieștile canoane în Biserică: între tradiție eclezială și necesitate pastorală. $O$ analiză a izvoarelor teologiei canonice in actualul context ecleziologic, Bucharest, 2017;

[62] Grigoriță Georgică, ,Întâietate și sinodalitate în dialogul teologic oficial dintre Biserica Ortodoxă și Biserica RomanoCatolică. Studiu canonic", in Ortodoxia 7 (2015), no. 1, pp. 104-177;

[63] Grigoriţ̆ Georgică, „Streitfragen im Dialog zwischen der Orthodoxen Kirche und der Romisch-Katholischen Kirche", in Dan Dungaciu (ed.), Sieben Hauptthemen für Rumänien im Jahr 2014, Bucharest, 2015, pp. 709-725;

[64] Grigoriț̆̆ Georgică, „Autocefalia în Biserica Ortodoxă. Studiu canonic”, in Autocefalia: libertate și demnitate, Bucharest, 2010, pp. 65-82;

[65] Guilland Rodolphe, „Le droit divine à Byzance”, in Seorsum impressum ex commentariis Societatis Philologae Polonorum XLII (1947), p. 139-150;

[66] Icăjr. Ioan, Canonul Ortodoxiei. Canonul apostolic al primelor secole, Sibiu, 2008;

[67] Ivan Iorgu, ,Principii de organizație și disciplină bisericească în canoanele Sinodului al IV-lea ecumenic", in Telegraful Român 100 (1952), no. 7-8, pp. 2-4;

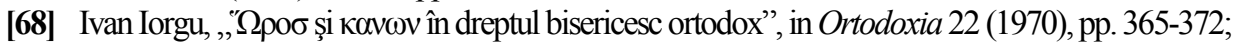

[69] Ivan Iorgu, ,Importanţa principiilor fundamentale canonice de organizație şi administraţie, pentru unitatea Bisericii”', in Mitropolia Moldovei şi Sucevei 45 (1969), pp. 155-165;

[70] Joannou Périclès-Pierre, La législation impériale et la christianisation de l'Empire romain (311-476), Rome, 1972;

[71] Karabélias Évanghélos, „Le droit ecclésiastique byzantin dans ses rapports avec le droit impérial (du $4^{\mathrm{e}}$ au $12^{\mathrm{e}}$ siècle)”,

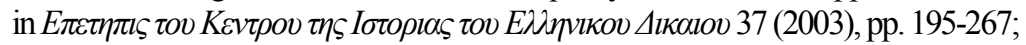

[72] Karanicolas Panteleimon, „Synodical Legislation and State Ecclesiastical Laws”, in Ecoioría 52 (1981), pp. 217-227;

[73] Karmiris Ioannis, „The Distinction between the «Horoi» and the «Canons» of the Early Synods and their Significance for the Acceptance of the Council of Chalcedon by the Non-Chalcedonian Churches", in Greek Orthodox Theological Review 16(1971), pp. 79-107;

[74] Kéry Lotte, Canonical Collections of the Early Middle Ages (ca. 400-1140) . A Bibliographical Guide to the Manuscripts and Literature, Washington, 1999;

[75] Kniazeff Alexis, „La place de la loi de l'Eglise dans la tradition de l'Orthodoxie”, in Unité Chrétienne 76 (1984), pp. 61 73 ;

[76] Kniazeff Alexis, „Le Royaume de César et le Règne de Dieu”, in Contacts 39 (1987), pp. 265-278, 40 (1988), pp. 1936 ;

[77] Lalmant Maurice, „Canon”, in Raoul NAZ (ed.), Dictionnaire de droit canonique, t. II, Paris, 1937, col. 1283-1284;

[78] Lanata Giuliana, Legislazione e natura nelle Novelle giustinianee, Naples, 1984;

[79] Lanata Giuliana, ,Du vocabulaire de la loi dans les Nouvelles de Justinien”, in Subseciva Groningana 3 (1989), pp. 3748 ;

[80] Lust Johan-EynikelErik-Hauspie Katrin, A Greek-English Lexikon of Septuagint, Stuttgart, 2003;

[81] L'Huillier Pierre, ,Le concile œecuménique comme autorité suprême dans l'Eglise”, in Kanon 2 (1974), pp. 128-142;

[82] Macrides Ruth, „Nomos and Kanon on paper and in court”, in Rosemary Morris (ed.), Church and People in Byzantium, Birmingham, 1990, pp. 61-85;

[83] Maghioros Nikos, La recezione della normativa conciliare nel diritto imperiale in materia di fede conservato nel Cth. $X V I$, Rome, 1998;

[84] Maghioros Nikos, „Lineamenti della normativa conciliare canonica dal 313 al 425”, in Il diritto romano canonico quale diritto proprio delle comunità cristiane dell'Oriente mediterraneo. IX Colloquio internazionale romanistico canonistico, Città del Vaticano, 1994, pp. 365-453;

[85] Malgorzata Leszka B., „The Attitude of Early Byzantine Emperors towards the Process of Electing Bishops of Constantinople", in Mélanges d'histoire byzantine offerts à Oktawiusz Jurewicz à l'occasion de son soixante-dixième anniversaire, Lódź, 1998, pp. 110-127;

[86] Marga Irimie, „Theology of Orthodox Canon Law”, in Casian Rușeț (ed.), Simpozion international „,Statutul actual pentru organizarea și funcționarea Bisericii Ortodoxe ROmâne”: Carasenbeș, 2015, Cluj-Napoca-Caransebeș, 2016, pp. 128-143;

[87] Marga Irimie, ,Actualitatea sfintelor canoane”, in Revista Teologică 12 (2002), no. 3, pp. 41-46;

[88] Messner Francis, Dictionnaire droit des religions, Paris, 2015;

[89] Messner Francis, „Du droit ecclésiastique au droit des religions: évolution d'une terminologie”, in Revue de Droit Canonique, 47 (1997), no. 1, pp. 143-160; 
[90] Mircea Ioan, „Organizarea Bisericii și viaţa primilor creștini după Faptele Apostolilor”, in Studii Teologice 7 (1955), no. 1-2, pp. 64-92;

[91] Mihoc Vasile, „Canonul și inspirația Sfintei Scripturi văzute din punct de vedere orthodox”, in Ortodoxia 41 (1989), no. 3, pp. 20-30 [republished in Ortodoxia 48 (1997), no. 1-2, pp. 23-33];

[92] Milaș Nicodim, Drept bisericesc oriental, Bucharest, 1915, pp. 65-92;

[93] Moisiu Liviu-Claudiu, „Principii de organizare și disciplină bisericească în canoanele Sinodului III ecumenic”, in Studii Teologice 36 (1984), no. 9-10, pp. 656-666;

[94] Moldovan Ilie, ,Sfintele canoane și raportul lor cu revelația divină”, in Ortodoxia 28 (1976), no. 2, pp. 365373[republished in Mitropolia Banatului 28 (1977), no. 1-3, pp. 101-114];

[95] Mörsdorf Klaus, „Altkanonisches «Sakramentsrecht». Eine Auseinandersetzung mit den Anschauungen Rudolph Sohm über die inneren Grundlagen des Decretum Gratiani”, in Studia Gratiani 1 (1953), pp. 483-503;

[96] Munteanu Alexandru-Armand, „Aplicarea epitimiilor în lumina sfintelor canoane”, in Studii Teologice 13 (1961), pp. 445-465;

[97] Nikolakopoulos Konstantin, Imnografia ortodoxă la început și astăzi. Dicționar de termini liturgici şi imnologici, Bucharest, 2015;

[98] Ohme Heinz, Kanon ekklesiastikos. Die Bedeutung des altkirchlichen Kanonbegriffes, Berlin-New York, 1998;

[99] Ohme Heinz, „Kanon I (begriff)”, in Franz Joseph Dölger (ed.), Reallexikon für Antike und Christentum, vol. 20, Stuttgart, 2004, pp. 1-28;

[100] Ohme Heinz, „Der Kanon-Begriff der Synode von Nizäia (325)”, in Studia Patristica 29 (1997), pp. 310-315;

[101] Oppel Herbert, Kavóv. Zur Bedeutungsgeschichte des Wortes und seiner lateinischen Entsprechungen (RegulaNorma), Leipzig, 1937;

[102] Papathanassiou Ghinis Dimitrios, Théologie et pastorale des pénitences (epitimia) selon l'Eglise orthodoxe, Strasbourg, 1981

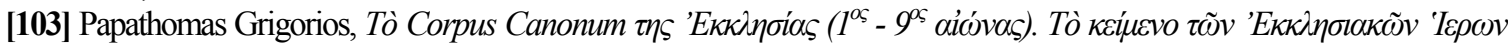
Kavóvwv. Le Corpus canonum de l'Eglise ( $1^{e r}-9^{e}$ siècles). Le texte des Saints Canons ecclésiaux, Katerini, 2015;

[104] Patlagean Évelyne, „Théologie politique de Byzance. L'empereur, le Christ, le patriarche”, in G. Filoramo (ed.), Teologie politiche. Modelli a confronto, Brescia, 2005, pp. 149-161;

[105] Patsavos Lewis J., Valențele duhovnicești ale Sfintelor Canoane, Sibiu, 2012;

[106] Pătrulescu Grigore, ,Epitimiile canonice și ascetice în general”, in Studii Teologice 32 (1980), pp. 535-550;

[107] Perșa Răzvan, „Sensurile termenului kovóvv în Tradiția canonică a Bisericii Ortodoxe în primele patru secole”, in Astra Salvensis 4 (2016), nr. 7, pp. 20-39;

[108] Phidas Vlasios, Droit canon. Une perspective orthodoxe, Chambésy, 1998;

[109] Pitsakis Konstantinos, „Les novelles dans le droit canonique oriental”, in Luca Loschiavo-Giovanna Mancini-Cristina Vano (ed.), Novellae Constitutiones: l'ultima legislazione di Giustiniano tra Oriente e Occidente da Triboniano a Savigny: atti del convegno internazionale, Teramo, 30-31 ottobre 2009, Naples, 2011, pp. 91-109;

[110] Pitsakis Konstantinos, „Droit romain et droit canonique oriental”, in Cristianità d'Occidente e cristianità d'Oriente (secoli VI-XI): 24-30 aprile 2003, Spoleto, 2004, vol. 2, pp. 1435-1469;

[111] Pitsakis Konstantinos, „Sainteté et empire. A propos de la sainteté impériale: formes de sainteté «d'office» et de sainteté collective dans l'Empire d'Orient?', in Bizantinistica III (2001), p. 155-227;

[112] Pitsakis Konstantinos, „L'empereur romain d'Orient: un laïc”, in Kanon 15 (1999), pp. 196-221 ;

[113] Pitsakis Konstantinos, „Quelques réflexions au sujet d'individu et pouvoir dans l'Empire romain d'orient: idéologie politique et pensée canonique", in Méditeranées 16(1998), pp. 138-166;

[114] Pitsakis Konstantinos, „Ius Graeco'Romanum et normes canoniques dans les Eglises de tradition orthodoxe”, in Raffaele Coppola (ed.), Atti del Congresso Internazionale ,Incontro fra canoni d'Oriente e d'Occidente, vol. 1, Bari, 1994, pp. 99-132;

[115] Pitsakis Konstantinos, „La $\sigma \cup v \alpha \lambda \lambda \eta \lambda \jmath \alpha$ principe fondamental des rapports entre l'Eglise et l'Etat (Idéologie et pratique byzantines et transformations contemporaines)", in Kanon 10 (1991), p. 17-35;

[116] Pitsakis Konstantinos, „Empire et Eglise le modèle de la Nouvelle Rome: la question des ordres juridiques”, in Maria Pia Baccari, (ed.), Diritto e religione. Da Roma a Costantinopoli a Mosca. Rendiconti del XI Seminario «Da Roma alla terza Roma». Campidoglio, 21 aprile 1991, Rome, 1994, pp. 101-126;

[117] Preda Constantin, Credința și viața Bisericii primare. O analiză a Faptelor Apostolilor, Bucharest, 2002;

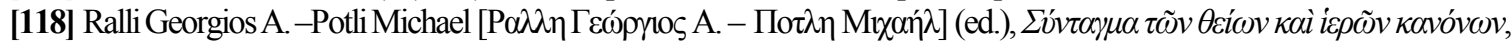
vol. IV, Athens, 1854;

[119] Righi Roberto, ,Rudolph Sohm e il diritto canonico”, in Carlo Fantappiè (ed.), Itinerari culturali del diritto canonico nel Novocento, Torino, 2003, pp. 33-71;

[120] Roberti Melchiorre, „Le associazioni funerarie cristiane e la proprietà ecclesiastica nei primi tre secoli”, in Studi dedicati alla memoria di Pier Paolo Zanzucchi, Milan, 1927, pp. 89-113; 
[121] Rodopoulos Panteleimon, ,Sacred canons and laws”, in Kanon 10 (1991), pp. 9-15;

[122] Roman Emilian-Iustinian, ,Kavó́v - chintesența legislației bisericești actuale", in C. DRON, Valoarea actuală a canoanelor, Iași, 2016, pp. 23-46;

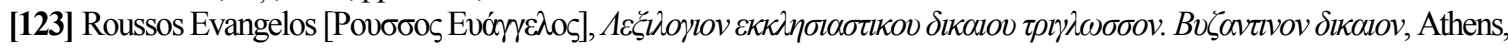
1948;

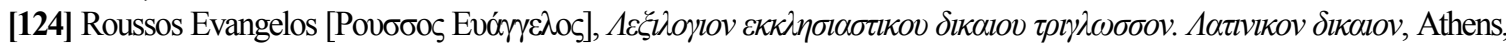
1949;

[125] Rus Constantin (ed.), The place of Canonical Principles in the Organization and Working of Autocephalous Orthodox Churches. The Canon Law International Symposium (Arad, 10-12 September 2008), Arad, 2008;

[126] Rus Constantin, Canomul cărților Sfintei Scripturi după canoanele Bisericï Ortodoxe, Arad, 2001;

[127] Rus Constantin, Drept bisericesc, Arad, 2000;

[128] Rus Constantin, „Canoanele Bisericii și funcția lor ecleziologică”, in Altarul Banatului 11 (2000), no. 7-9, pp. 37-46;

[129] Rus Constantin, ,Principii de organizare și disciplină bisericească în canoanele Sinodului VII ecumenic de la Niceea din anul 787", in Mitropolia Banatului 37 (1987), no. 2, pp. 40-57;

[130] Rușescu Ion-Gheorghe, ,Principii și dispoziții de organizare și disciplină în canoanele Sinodului VI ecumenic”, in Studii Teologice 35 (1983), no. 1-2, pp. 64-78;

[131] Sáez Gutiérrez Andrés, Canon y autoridad en los dos primeros siglos. Estudio histórico-teológico acerca de la relación entre la Tradición y los escritos apostólicos, Rome, 2014;

[132] Sanctus Climentis, Epistola ad Corinthios in PG I, col. 199-328;

[133] Saradi Helen, „The Byzantine Tribunals: Problems in the Application of Justice and State Policy $\left(9^{\text {th }}-12^{\text {th }} \text { c.) }\right)^{\text {", in Revue }}$ des études byzantines 53 (1995), pp. 165-204;

[134] Schminck Andreas, ,Leges ou nomoi ?’, in Spyridon Flogaitis - Antoine Pantelis, The Eastern Roman Empire and the Birth of the Idea of State in Europe, London, 2005, pp. 309-316;

[135] Sesboüé Bernard, Histoire et théologie de l'infaillibilité de l'Eglise, Bruxelles, 2013;

[136] Sohm Rudolph, Das altkatholische Kirchenrecht und das Dekret Gratians, Munich, 1918;

[137] Spulber Constantin A., Le concept byzantin de la loi, Bucharest, 1938;

[138] Stan Liviu, „Despre canonizarea sfinților în Biserica Ortodoxă”, in Ortodoxia 2 (1950), pp. 260-278;

[139] Stan Liviu, ,Relațiile dintre Biserică și Stat”, in Ortodoxia 4 (1952), pp. 353-461;

[140] Stan Liviu, „Legislația bisericească și valoarea ei canonică”, in Mitropolia Olteniei 6 (1954), no. 11-12, pp. 598-617;

[141] Stan Liviu, ,Biserica și Dreptul', in Mitropolia Olteniei 8 (1956), no. 8-9, pp. 482-489;

[142] Stan Liviu, „Codificarea canoanelor”, in Studii Teologice 12 (1960), no. 7-8, pp. 627-648;

[143] Stan Liviu, ,Jus ecclesiasticum. Dreptul în viața Bisericii”, in Studii Teologice 12 (1960), no. 7-8, pp. 467-483;

[144] Stan Liviu, „Legislația Bisericii Ortodoxe Române în timpul arhipăstoririi Preafericitului Părinte Patriarh Justinian. Principiile canonice de bază ale Ortodoxiei oglindite în legislația Bisericii Ortodoxe Române", in Ortodoxia 20 (1968), no. 2 , pp. 267-296;

[145] Stan Liviu, „Canonizarea sfinților după învăț̆ătura și după rânduielile Ortodoxiei”, in Mitropolia Olteniei 20 (1968), pp. 360-368;

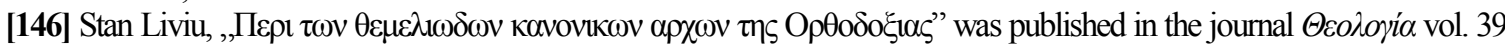
(1968), no. 1-2 (January-February), pp. 5-18;

[147] Stan Liviu, „Tăria nezdruncinată a sfintelor canoane”, in Ortodoxia 22 (1970), pp. 300-304;

[148] Stan Liviu, „Despre principiile canonice fundamentale ale Ortodoxiel”, in Autocefalia. Libertate și demnitate, Bucharest, 2010, pp. 18-25;

[149] Stan Liviu, „Despre principiile canonice fundamentale ale Ortodoxiel”, in Revista Teologică 20 (2010), no. 3, pp. 175185 ;

[150] Stăniloae Dumitru, Teologia Dogmatică Ortodoxă, vol. 2, Bucharest, 1997;

[151] Stăniloae Dumitru, „Noțiunea dogmei”, in Studii Teologice 16 (1964), no. 9-10, pp. 533-571;

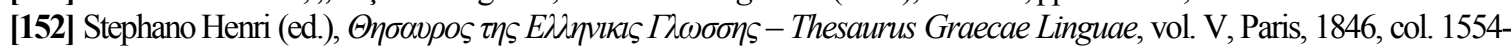
1555 ;

[153] Steimer Bruno, Vertex Traditionis. Die Gattung der altchristlichen Kirchenordnungen, Berlin-New York, 1992;

[154] Stolte Bernard H., ,Of Nomoi and Kanones”, in Subseciva Groningana 6 (1999), pp. 121-136;

[155] Straub Johannes A., „Constantin as Korvos Елıбкотоб: Tradition and Innovation in the Representation of the First Christian Emperor's Majesty", in Dumbarton Oaks Paper 21 (1967), pp. 37-55;

[156] Sundberg Jr. Albert C., „Canon Muratori: A Fourth-Century List”, in The Harvard Theological Review 66 (1973), no. 1, pp. 1-11;

[157] Şesan Valerian, „Revizuirea canoanelor şi a altor norme bisericești, precum şi codificarea lor”, in Candela 47 (1936), pp. 145-159;

[158] Tofană Stelian, Introducere în Noul Testament: Test și Canon, vol. 1, Cluj Napoca, 1997; 
[159] Troianos Spyros, Le fonti del diritto bizantino, Torino, 2015;

[160] Troianos Spyros, „Byzantine Canon Law to 1100”, in Wilfried Hartmann - Kenneth Pennington (ed.), The History of Byzantine and Eastern Canon Law to 1500, Washington, 2012, pp. 115-169;

[161] Troianos Spyros, „Nomos und kanon in Byzanz”, in Kanon 10 (1991), pp. 37-51;

[162] Troplong Raymond Théodore, De l'influence du Christianisme sur le droit civil des romains, Paris, 1843;

[163] Van Der Wal Nicolaas, Manuale Novellarum Justiniani. Aperçu systématique du contenu des Nouvelles de Justinien, Groningen-Amsterdam, 1964;

[164] Verkhovskoy Serge, „The Highest Authority in the Church”, in Saint Vladimir's Theological Quarterly 4 (1960), pp. 76-88;

[165] Verpeaux Jean, Pseudo-Kodinos. Traité des offices, Paris, 1966;

[166] Viscuso Patrick, „A Late Byzantine Theology of Canon Law”, in The Greek Orthodox Theology Review 34 (1989), pp. 203-219;

[167] Vismara Giulio, La giurisdizione civile dei vescovi (secoli I-LX), Milan, 1995;

[168] Von Linghental Zachariae, Jus Graecoromanum, vol. 2, Athens, 1931;

[169] Wagshal David, Law and the legality in the Greek East: The Byzantine Canonical Tradition, 381-883, Oxford, 2015;

[170] Wenger Leopold, Canon in den römischen Rechtsquellen und in den Papyri: eine Wortstudie, Wien, 1942;

[171] Wenger Leopold, „Über canon und regula in den römischen Rechtsquellen”, in Zeitschrift der Savigny-Stiftung für Rechtsgeschichte: Kanonistische Abteilung 32 (1943), pp. 495-506;

[172] Winroth Anders, The Making of Gratian's Decretum, Cambridge, 2000;

[173] Yannopoulos Panayotis A., „Le couronnement de l'empereur à Byzance: rituel et fond institutionnel”, in Byzantion 61 (1991), pp. 71-91;

[174] Žužek Ivan, „Sacralità e dimensione umana dei canones”, in Silvano Agrestini - Danilo Ceccarelli Morolli (ed.), Ius ecclesiarum vehiculum caritatis. Atti del simposio internazionale per il decennale dell'entrata in vigore del Codex Canonum Ecclesiarum Orientalium, Città del Vaticano 19-23 novembre 2001, Città del Vaticano, 2004, pp. 53-116;

[175] Žužek Ivan, „A Code for the Orthodox Churches”, in Concilium 8 (1969), pp. 74-79. 